\title{
Evangelical Women and Secular Society in New Zealand: An Investigation into Feminism as an Ideology of Empowerment
}

\author{
By
}

Lydia A. Ellis

A thesis submitted to Victoria University of Wellington in fulfilment of the requirements for the degree of Master of Arts in Religious Studies

School of Art History, Classics and Religious Studies

Victoria University of Wellington

2012 


\begin{abstract}
This thesis examines the resurgence of evangelicalism in New Zealand and the conflicting nature of the lives that evangelical women in New Zealand live. Evangelicalism in New Zealand is growing and evolving and thus evangelical women are by necessity adapting to their secular setting whilst maintaining their faith. This study reveals many interesting findings, illustrating the often contradictory and challenging issues that evangelical women must face as they identify with feminism as a secular symbol while maintaining a conservative evangelical faith. Evangelical women in New Zealand today are living in two worlds. The women have a strong sense of identity and faith within evangelicalism however there are contradictions. Simultaneously there is a strong influence of secular liberal society which is evident through the women's identification with feminist values. What has been discovered is that evangelical women can successfully live in two separate worlds - one secular and one religious. They can be women of faith while at the same time living their lives in a secular society. Similarly there is a significant gap between rhetoric and reality in evangelical women's lives - what evangelical women articulate regarding gender roles in theory is not necessarily what occurs in practice. These challenges are defined by society and thus are a useful tool to assist in the understanding of the conflicts evangelical women have to negotiate on a daily basis.
\end{abstract}




\section{ACKNOWLEDGEMENTS}

I wish to offer my sincere thanks to my Supervisor Professor Paul Morris. Without your inspiration this thesis would never have been produced. Thank you for allowing me the opportunity to explore this field. The Religious Studies Department at Victoria University has offered me so much and it has been a pleasure to research among the talented staff and students here.

I am thankful to the wonderful people I dealt with at the Rock, Lighthouse Christian Fellowship and Lifepoint for allowing me in your churches for research and for encouraging women from your congregations to participate. Without participants there would be no research, therefore I am extremely appreciative to the 20 women I have interviewed and have had the privilege to meet over the course of this study.

To my mother Karyn Fenton-Ellis who has not only tirelessly proof-read this thesis, but has also read every piece of work I have written - thank you does not even begin to describe how much you have helped me. Without your constant love and support I would not be where I am today. I am indebted to you always. To the rest of my family David Ellis, Julia-Rose Bisdee, Sylvia Fenton, James Rae and Mitchell Wagstaff thank you for your encouragement, help and interest while writing this thesis, it will never be forgotten. 


\section{TABLE OF CONTENTS}

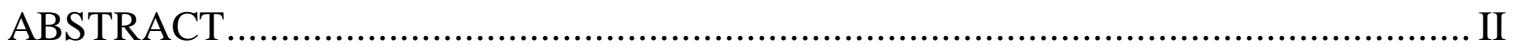

ACKNOWLEDGEMENTS .............................................................................. III

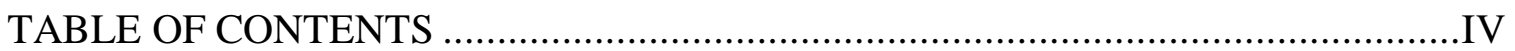

\section{CHAPTER ONE INTRODUCTION}

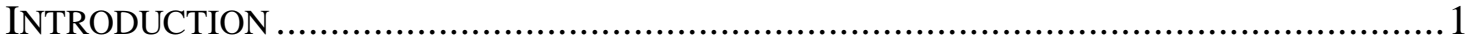

EVANGELICALISM AND FEMINISM - BACKGROUND ................................................. 4

PURPOSE OF THE STUDY - WHY EVANGELICAL WOMEN?...........................................

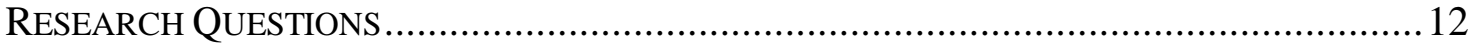

THE SignifiCANCE OF STUdy TO THE FIELD OF RELIGIOUS STUDIES ..........................13

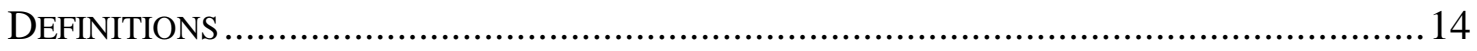

The Statement of THE Problem ........................................................................ 20

\section{CHAPTER TWO LITERATURE REVIEW}

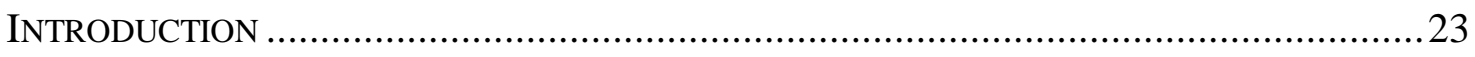

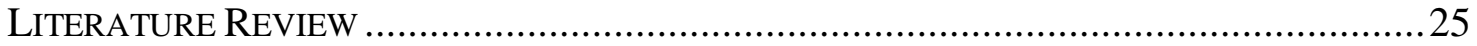

Global Evangelicalism - A Multi-Faceted Reality ..............................................26

The Evangelical Scene in New Zealand .......................................................... 33

New Zealand Feminist Theorists ................................................................. 41

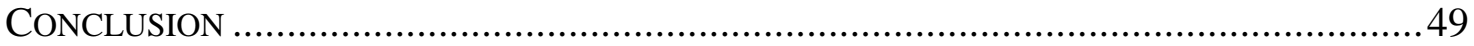

\section{CHAPTER THREE METHODS}

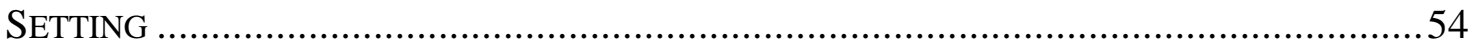

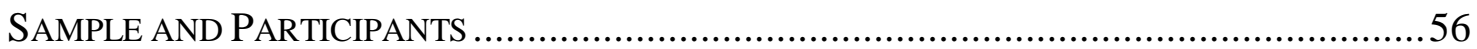

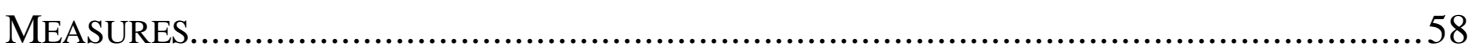


DATA CoLLECTION AND PROCEDURES..............................................................60

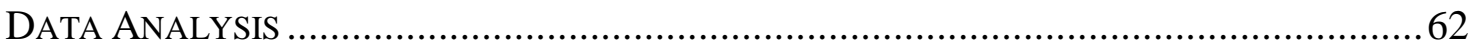

\section{CHAPTER FOUR RESULTS}

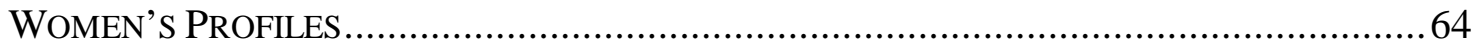

LIVING IN TWO WORLDS - EVANGELICAL WOMEN'S EXPERIENCE ............................. 70

The Difficulties of Being an Evangelical Christian ............................................. 70

Challenges from Non-Christians in Secular Society ..........................................73

WOMEN’S ROLE IN CHURCH AND SOCIETY ........................................................ 75

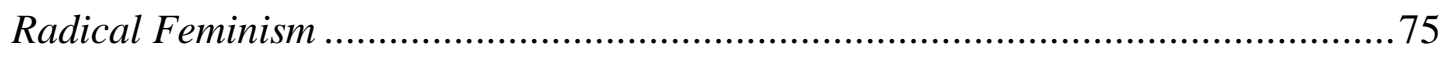

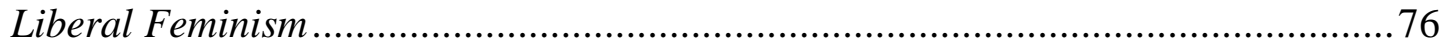

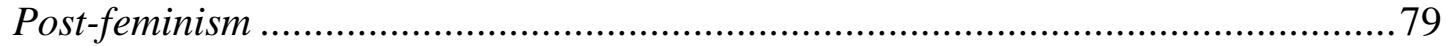

THE FuLFILMENT OF EVANGELICAL WOMEN ................................................... 81

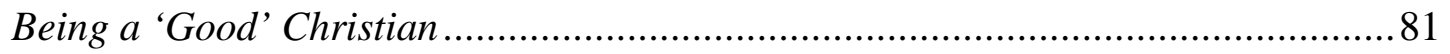

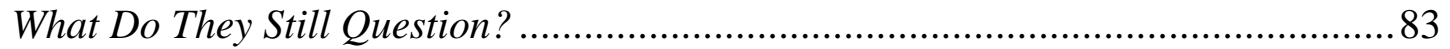

The Best Thing about Being an Evangelical Woman........................................... 85

\section{CHAPTER FIVE DISCUSSION}

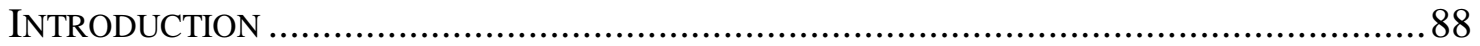

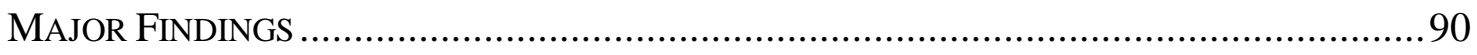

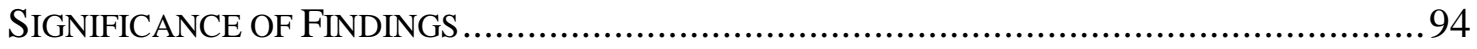

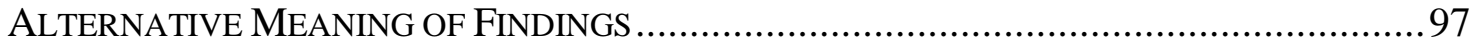

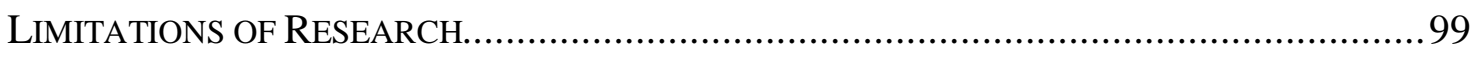

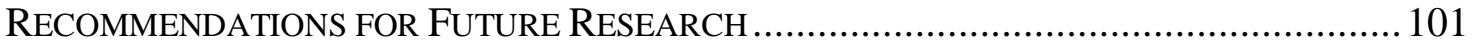

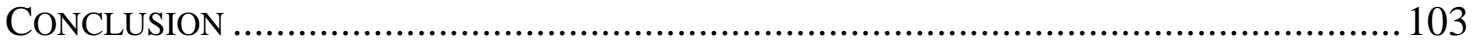

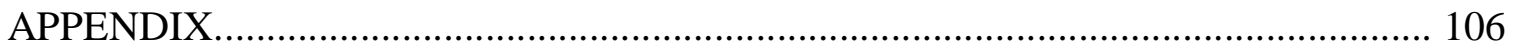

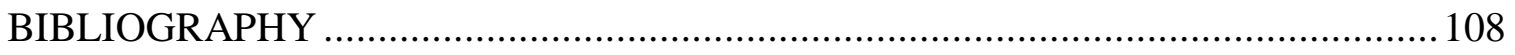




\section{CHAPTER ONE}

The gospel's most dangerous earthly adversaries are not raving atheists who stand outside the door shouting threats and insults. They are church leaders who cultivate a gentle, friendly, pious demeanour but hack away at the foundations of faith under the guise of keeping in step with a changing world. ${ }^{1}$

\section{Introduction}

For feminists, evangelicalism represents oppression. It has patriarchy intertwined through its core principles and belief systems and this cannot be undone - it is the evangelical identity. For feminists, evangelicalism stands for everything that suppresses the freedom, personality and identity of women. It further oppresses women with antiabortion positions and imposes barriers to women in church leadership. It is radical and it is discriminatory. Evangelicalism represents divisive conflict regarding the oppression of women; so how can evangelical churches attract and retain membership at record levels when a significant percentage of the congregation is female and such discrimination exists? New Zealand evangelical women distance themselves from this definition of evangelicalism. However, evangelical churches in New Zealand are experiencing times of significant growth in the enrolments in, and programmes and involvement of, evangelical institutions while other religious groups are declining or

\footnotetext{
1 Phil Johnson, “The Neo-Liberal Stealth Offensive,” (2010), http://www.9marks.org/ejournal/byauthor/phil-johnson (accessed 13 December, 2010).
} 
maintaining the status quo. ${ }^{2}$ What is facilitating this growth? How do evangelical women in New Zealand integrate their faith with modern, contemporary life?

New Zealand evangelical women are not characteristic of the fundamentalist stream as found in the United States; they are a distinctive group and they challenge the boundaries between secular and religious. They are typical and atypical at the same time - they experience conflicts and express contradictions, which is portrayed in the obvious chasm between rhetoric and reality that evangelical women must negotiate. Influencing this negotiation is the fact that evangelical women live in an ever-changing society where religion has had to adapt to secularity or be left behind, even more so than they are in popular perception. This leads to women attempting to live in both a secular and a religious world and having to negotiate the many challenges that come with that. Women are thus influenced by secular society and are experiencing attitudinal change which facilitates these negotiations. This has created changes in the way evangelical women perceive gender roles - the traditional view of the man as leader with the woman as follower, is declining in relevance to the post-modern evangelical woman; values such as pay equity, shared domestic labour and the necessity of two incomes increase in importance. Evangelical women are confirming their identities as autonomous and independent women of faith within a secular context and are redefining gender roles significantly.

Few issues have divided the church more dramatically in recent times than the role of women. It has driven emotive and often extreme opinion and action across all sectors of society, including the practicing Christian sector. Women and religion have long been the subject of intense concern and fierce protest globally, fuelling countless emotive and

\footnotetext{
${ }^{2}$ John M. Hitchen, "What It Means to be an Evangelical Today - An Antipodean Perspective: Part One Mapping Our Movement,” EQ 76:1 (2004): 47-64.
} 
often irrational debates. In most religions in the world, the subject of women's place divides opinion, leading to a polarised community. From time immemorial women have answered to men in family, the political arena and in business, often with limited rights within the church and even limited participation in public life. It is not only among evangelicals that equal rights for women are a great unfulfilled concern - there is apprehension among sacred and secular communities globally. The ability of women to have the same dignity and rights in evangelicalism as men is a particularly explosive issue.

Over the last decade, feminism among evangelical women has catapulted into the public sphere, with literature and academia at the forefront. Evangelical feminism was distinct from the rest of evangelicalism because of its social progressivism on issues of women's equality, and at the same time it distinguished itself from secular feminism by insisting on the centrality of biblical authority on the relationship of church to society. ${ }^{3}$ The importance of feminist issues and evangelicalism has become a phenomenon in evangelical circles. It continues to be a significant discourse for research, paving the way for women in religion to be systematically analysed over centuries throughout the world. Although women comprise the majority of church attendees, and some studies show that women, in fact, drive most faith participation, the obvious lack of women in active church leadership roles has been widely researched. ${ }^{4}$ This raises questions about how women manage this apparent marginalisation while at the same time living as liberated women in a secular society.

\footnotetext{
${ }^{3}$ Pamela D. H. Cochran, Evangelical Feminism: A history. (New York, London: New York University Press, 2005), 9.

${ }^{4}$ Barna Group, "Who is Active in 'Group' Expressions of Faith? Barna Study Examines Small Groups, Sunday School and House Churches," www.barna.org/faith-spirituality/400-who-is-active-in-groupexpressions-of-faith-barna-study-examines-small-groups-sunday-school-and-housechurches?q=church+attendance (accessed 10 December, 2010).
} 


\section{Evangelicalism and Feminism - Background}

\section{Evangelicalism}

The term 'evangelical', as designating a particular religious identity came into prominence in the seventeenth and eighteenth centuries, although it had already appeared in the Reformation period as a point of conflict between a rising Protestantism and Roman Catholicism. In the nineteenth and twentieth centuries, evangelicalism became increasingly contrasted with modernism and liberalism. ${ }^{5}$ George Marsden outlines a foundational definition of evangelicalism stating that it is a multidenominational group characterised by its belief in the Reformation doctrine of the final authority of the Bible, the real historical character of God's saving work in scripture, salvation to eternal life based on the redemptive work of Christ, the importance of evangelism and mission and finally, the importance of a spiritually transformed life. ${ }^{6}$ Unlike Marsden's definition where there is an emphasis on a lifestyle change through religion, evangelical religion as expressed by women in this research does not have a rigid adherence to a distinct lifestyle - it is defined by the individual experience of God and church membership. The ethos of evangelicalism focuses on an individual relationship with God. It facilitates individualism within a community and places value on autonomy and on choice. Evangelicals' faith involves a personal relationship with Jesus Christ, one that needs to be constantly renewed through daily experience. Grace is seen as the source of faith and faith comes from the Holy Spirit. ${ }^{7}$ What sets

\footnotetext{
${ }^{5}$ Donald G. Bloesch, “Evangelicalism,” DIALOGUE: A Journal of Theology 47:1 (2008): 16-20.

${ }^{6}$ George M. Marsden, Understanding Fundamentalism and Evangelicalism (Grand Rapids, Michigan: Wm. B. Eerdmans Publishing Co., 1991), 2-3.

${ }^{7}$ Donald G. Bloesch, “Evangelicalism,” DIALOGUE: A Journal of Theology 47:1 (2008): 16-20.
} 
evangelicalism apart from most traditional orthodoxy is its emphasis on the visible, personal return of Christ. ${ }^{8}$

New Zealand evangelical culture is distinctive. The post-World War II rise of evangelicalism in New Zealand stemmed from the growth of the Inter-Varsity Fellowship (IVF) and the National Association of Evangelicals (NAE). After World War II, the IVF was often seen as a de facto leader of New Zealand evangelicalism. ${ }^{9}$ In 1950 the United States National Association of Evangelicals (NAE) wished to establish links with evangelicals in New Zealand. ${ }^{10}$ The NAE did not aspire to establish a branch in New Zealand; rather its focus was on stimulating the development of similar evangelical movements globally. When NAE members visited New Zealand, its theological position paralleled that of New Zealand's evangelical leadership which was represented by the IVF. ${ }^{11}$ The New Zealand Evangelical Union and IVF movements grew steadily in the period from 1945 to 1965 . The IVF's expansion reflected the postwar growth of evangelicalism in New Zealand. It emphasised biblical orthodoxy, the rational defence of Christian faith and student evangelism. ${ }^{12}$ The movement had a crucial role in defining, defending and unifying New Zealand evangelicalism - it shaped evangelicalism in New Zealand. The movement emphasised moderation that is clearly reflected in evangelicalism in today's society. It set the precedent for the expansion of evangelicalism today - Pentecostals were the only major Christian group in New

\footnotetext{
${ }^{8}$ Donald G. Bloesch, “Evangelicalism,” DIALOGUE: A Journal of Theology 47:1 (2008): 16-20.

${ }^{9}$ Stuart Lange, "A Rising Tide: The Growth of Evangelicalism and Evangelical Identity among Presbyterians, Anglicans and University Students in New Zealand, 1930-1965," (PhD Thesis, University of Otago, 2008), 377.

${ }^{10}$ Ibid.

${ }^{11}$ Ibid., 380

${ }^{12}$ Stuart Lange, Ibid., 391.
} 
Zealand to experience significant growth between 1991 and 1996, with their numbers increasing by 55 percent; this growth has continued in the years since. ${ }^{13}$

Evangelicals today are forging a new identity - not a refurbished fundamentalism but a new way of stating old truths. ${ }^{14}$ Evangelicalism is developing - it is growing and changing in a way that is relevant to New Zealand society. Evangelical women want to have it all and they are now challenging the traditional evangelical norm by asking 'why not?' Evangelicalism in New Zealand is fluid and flexible - it does not attempt to answer 'why not?' Instead it allows individuals to be a part of something larger - faith and society simultaneously. This is something that secular women cannot experience as it is limited to Christian women. It is what makes them unique in their religiosity. Evangelicalism in New Zealand is growing not only because it cuts across denominational boundaries, but because it allows adherents to be both individuals of faith within a community, and individuals in a secular society.

\section{Feminism in New Zealand}

Historically, feminism was significant in shaping New Zealand society. New Zealand has led the world in women's rights, from the pioneering of the early temperance movement to the more recent abortion law reform. Feminism is deeply embedded in our political system with legislation such as the Property (Relationships) Act 1976, which enabled fair access to the division of property for married, de facto and civil union couples when they separate or one of them dies, the Human Rights Act $1993,{ }^{15}$ which

\footnotetext{
${ }^{13}$ This included 'Born Again' which is now included in 'Evangelical, Born Again and Fundamentalist'. "Religion and Ethnicity Source: New Zealand Official Yearbook 2000," http://www2.stats.govt.nz/domino/external/web/nzstories.nsf/0/553e95d870abb153cc256b1e0080ad44?O penDocument (accessed 19 May, 2010).

${ }^{14}$ Donald G. Bloesch, “Evangelicalism,” DIALOGUE: A Journal of Theology 47:1 (2008): 16-20.

${ }^{15}$ Originally the Human Rights Commission Act 1979.
} 
prohibits discrimination on the grounds of gender, and the Prostitution Reform Act 2003 which decriminalised prostitution in New Zealand. The women's liberation movement of the 1960's and 1970's challenged traditional gender roles head-on. The feminist movement refuted the idea that the place of women was in the home and that the paid workforce was a man's domain. New Zealand women had experienced workforce labour when they assumed their husbands' employment during World War II. The return to domesticity was therefore difficult for many women.

The New Zealand Sunday Herald sponsored Germaine Greer's visit to New Zealand in 1972 and, for the first time in New Zealand, a radical women's liberationist was given significant news media coverage. ${ }^{16}$ Suddenly the dangerously subversive ideas of women's liberation were being discussed on prime time television and on the front pages of the nation's daily newspapers, giving the movement a legitimacy it had never previously experienced; through these events thousands of New Zealanders were introduced to feminism. ${ }^{17}$ The 1970 's saw campaigns for accessibility to safe and legal abortion and resulted in the Contraception, Sterilisation and Abortion Act 1977. Sue Kedgley shocked the 1972 Labour Party conference by publicly addressing the males stating "It is not your penis we have been envying all these years, but your freedom". ${ }^{18}$ In a recent interview Kedgley discussed her thoughts on her involvement in the feminist movement:

One of the issues that we were against in the early days of liberation was the way in which women were treated as sex objects in advertising and so forth; it was as though women's role in life was to be sexually pleasing to

\footnotetext{
${ }^{16}$ The Sunday Herald is now known as the Herald on Sunday.

17 Sue Kedgley, “Caught in the Crossfire - Women's Liberation in the Seventies," Speech, Seventies Conference at Te Papa, Wellington, New Zealand, December 4, 2004.

${ }^{18}$ Ibid.
} 
men and, really, women were expected to devote themselves or to subordinate themselves to a man and to spend their lives looking after men. $^{19}$

The Select Committee on Women's Rights was established in 1975. It found that the main cause of sexual inequality in New Zealand was the acceptance of different traditional roles for women and men. Thus measures were recommended to advance women’s opportunities in employment, education, the home and public life. ${ }^{20}$ Similarly, in 1975, the Women's Electoral Lobby of New Zealand, a non-partisan organisation, was established to encourage women to enter political life, act as a united political force and promote women's issues in the political arena. ${ }^{21}$ It is historical developments such as these and comments made by Kedgley that emphasise the entrenched position feminism maintains in New Zealand society. New Zealand has notable feminist scholars such as Phillida Bunkle, Jane Simpson, Marilyn Waring and Rosemary Du Plessis - all of whom have contributed significantly to the feminism debate. Women in New Zealand have a fiercely guarded and hard earned reputation for being passionate about their role in all facets of life.

\footnotetext{
${ }^{19}$ Catherine Delahunty and Sue Kedgley, "Who is Pat Triarchy?” Audio recording, the Green Party of Aotearoa, New Zealand, February 18, 2011.

${ }^{20}$ Statistics New Zealand (2005), "Focusing on Women," http://www.stats.govt.nz/browse_for_stats/people_and_communities/women/focusing-on-women.aspx (accessed 2 June, 2010).

${ }^{21}$ Ibid. Many significant changes and events aided women towards equality in New Zealand. Statistics New Zealand (see footnote 20) chronologically dates them for a more detailed reference.
} 


\section{Purpose of the Study - Why Evangelical Women?}

Christianity in New Zealand shows an overall decrease in affiliation. Nearly four out of 10 people did not specify a religious affiliation in the 2001 Census. $^{22}$ Similarly, in the 2006 Census just over 2 million people, or 55.6 percent of those answering the religious affiliation question, affiliated with a Christian religion (including Māori Christian). This compares with the 2001 Census, when 60.6 percent of people affiliated with a Christian religion. ${ }^{23}$ If Christianity is experiencing such decline, then why use evangelicalism as a case study? Evangelicalism is unique - its evolution and progression are challenging the decline in affiliation to Christianity. This makes evangelicalism topical as it is surviving, even thriving, in contrast to other varieties of Christianity, in an increasingly secular society. This raises questions about what the attraction is to a conservative religion in a secular post-modern society. A desire to remain relevant in New Zealand's secular society motivated changes within New Zealand's evangelical culture. These changes facilitated the growth of evangelical institutions and this has caused evangelical religion to fuse with secular society, adopting cultural changes to adjust itself to a changing world and maintain relevancy to its adherents. The on-going effect of this fusion has many consequences for evangelical women and the way they view their role as women in the world. This suggests a point of agreement between evangelicalism and feminism as evangelical women are reinventing traditional gender roles as a result of the changing nature of their religion. Thus this makes evangelicalism in the context of New Zealand society such a critical case study.

\footnotetext{
${ }^{22}$ Statistics New Zealand (2001), "Census Snapshot: Cultural Diversity,” http://www.stats.govt.nz/browse for stats/population/census_counts/census-snapshot-culturaldiversity.aspx (accessed 2 June, 2010).

${ }^{23}$ Statistics New Zealand (2006), "QuickStats about Culture and Identity,” http://www.stats.govt.nz/Census/2006CensusHomePage/QuickStats/quickstats-about-a-subject/cultureand-identity/religious-affiliation.aspx (accessed 2 June, 2010).
} 
The purpose of this study is to explore whether secular society influences evangelical women in such a way that feminism forms part of their identity. Gender roles are transforming and evangelical women have significant autonomy over their lives. Currently there is no literature that examines the role of feminism and liberal theory in the lives of evangelical women in New Zealand. Whether evangelical women are combating the contradictions between feminism and evangelicalism, and whether the two can be compatible, has not been researched in the New Zealand context. This situation of insufficient data is primarily due to a lack of research interest on the subject because religion in general is not considered as significant in a secular society such as New Zealand. The research interest to date has been reliant on scholarship from the United States and Britain. As evangelicalism continues to expand globally, the study of how women manage their faith within secular liberal society is becoming more relevant and important in today's context - and especially in New Zealand. Feminism is a significant factor in understanding and ascertaining how evangelical women negotiate the often-conflicting demands and rewards of their membership in their religious community and the larger society. There is a need for a contribution to contemporary scholarship on the role of evangelical women in their faith and in the wider New Zealand society. Not only will the research address a gap in current scholarship, it will build on influential studies from around the world to emphasise the challenging and sometimes contradictory position of evangelical women in the context of New Zealand society.

In order to identify evangelical women's perspectives on feminism, the researcher conducted interviews with 20 women from three churches in Wellington and Hamilton, New Zealand. The sample criterion was small. Participants were restricted to females. A 
demographic survey was conducted in order to target a cross-section of women in terms of age, ethnicity, education level and household income. There were unavoidable limitations in the selection process as the women had to contact the researcher voluntarily if they were willing to participate. To ascertain accurately the ideals of contemporary evangelical women's lives in New Zealand, a 60-minute interview was conducted, paying particular attention to how they grapple with feminism as well as liberal norms. ${ }^{24}$ Many in-depth questions which were prepared ahead of time were discussed to find out the nature of feminist values in the women's lives. In order to explore and describe how women interacted and participated in church worship, the researcher conducted observations at the churches during Sunday services.

The purpose of the research was to explore feminism from the perspective of evangelical women in New Zealand and to ascertain how effectively the women live in both a secular and religious world. By learning how these women identify with feminism, an insight is provided into the lives of evangelical women and clarifies the context where the issues are viewed from the participants' perspectives rather than imposing assumptions on them. This study also had implications for how evangelical women view their relationship with feminism and their church. The results show the very different and successful ways in which evangelical women negotiate the ideas that they have absorbed from the feminist movement and the views of women and gender roles as presented by their religious traditions. There are contradictory elements evangelical women have to deal with on a daily basis as they are immersed in secular liberal culture in New Zealand. Despite these challenges, the women studied have

\footnotetext{
${ }^{24} 60$ minutes on average. The length of the interviews was varied - some were 30 minutes and others were two hours.
} 
successfully integrated secular liberal culture in-to their faith by accepting feminist values.

\section{Research Questions}

The most pressing question to be answered by this research involves evangelical women's perceptions towards feminism. How do evangelical women use feminism as a way of coping with conflicting demands in New Zealand secular society? Women in evangelicalism are particularly interesting - what is it that makes modern twenty-first century women choose to belong to an institution that encompasses traditional values for women? For centuries women pioneered and strove to achieve equal status with men, as is reflected in the feminist movement worldwide. What is it that motivates the modern-day woman to be attracted to a faith that essentially reverts back to traditional gender roles? Is this not a step backwards in terms of women's liberties? What is fascinating is the fact that the feminist movement and the rise of evangelicalism in New Zealand occurred simultaneously but independently-thus they can be seen as parallel social forms. Many pioneering women, supporting both evangelical and feminist causes separately, joined forces on social matters such as the temperance movement and the banning of pornography. ${ }^{25}$ However, for most people, the terms evangelical and feminism are contradictory. How can an evangelical, who supports social conservatism and traditional gender roles, also support feminism, a movement that seeks to redress the inequalities, injustice and discrimination that women face because of their sex? Surely a person cannot hold true to a feminist ideology and a conservative theology at the same time? There is, however, significant literature related to evangelical feminism

${ }^{25}$ Elaine Storkey, What's Right with Feminism? (London: SPCK, 1985). 
- a belief that, when interpreted correctly, the Bible teaches the equality of women and men. It is possible that evangelical women have adopted feminist values, while maintaining a conservative theology, as a way of negotiating the conflicting demands placed on them by secular liberal society.

How can a woman be both a feminist and an evangelical? An evangelical women's conference in New Zealand had 500 women attend. Likewise the Christians for Biblical Equality International (CBE) Conference in Melbourne 2010 had a similar number of attendees. CBE, with its feminist undertones, fostered an interest to develop this phenomenon further and to research the views of women in evangelical churches in New Zealand. The initial finding was a lack of literature on evangelical women and their alliance with feminism in New Zealand.

\section{The Significance of Study to the Field of Religious Studies}

This research will contribute to further study on women and evangelicalism in New Zealand. Evangelicalism in New Zealand is a growing and developing phenomenon; however currently there is no literature that examines the role of feminism and liberal theory in the lives of evangelical women in New Zealand. Because in Religious Studies’ scholarship it is imperative to research historical and contemporary trends in religion the relationship between feminism and evangelicalism is significant. The dominance of literature from the United States emphasises the gap in scholarly material and illustrates the need for research to be conducted elsewhere. New Zealand is a poignant case study, as the growth of evangelicalism is increasing. Between 2001 and 2006 the number of

people affiliating with Evangelical, Born Again and Fundamentalist Christian 
denominations increased by 25.6 percent and affiliation with Pentecostal religions increased by 17.8 percent. ${ }^{26}$ This increase cannot be ignored and thus the study of how women manage their faith within secular liberal society is becoming more relevant and important in today's context. This study has uncovered important information about evangelical women's attitudes, perceptions and behaviours towards feminism, society and church life. The research has motivated the women interviewed as it has acted as a catalyst for them to discover or rethink how they view themselves as women of faith in contemporary society. It is hoped that the study will contribute to the field of Religious Studies as well as future studies on feminism and evangelicalism.

\section{Definitions}

Defining evangelicalism is an extremely difficult task and is debated among sociologists, historians of religion, and even evangelical theologians. In the sociological sense, the definition demarcates who is inside and who is outside the evangelical fold. It is for sociological reasons that historians such as George Marsden and Virginia Brereton have simplified the definition of evangelicalism. ${ }^{27}$ Furthermore, it is who you study that determines what you will find. It is not within the scope of this research to recall the extensive history of evangelicalism, as many authors such as George Marsden and Joel Carpenter have done so thoroughly. Generally, however, scholars agree that

\footnotetext{
26 'Evangelical, Born Again and Fundamentalist' are referred to as religious denominations by Statistics New Zealand in this context, not as a description as elsewhere in the thesis. Evangelical and Pentecostal are separate religious affiliations in the New Zealand Census; however, for the purposes of this research Pentecostalism is included in the broad evangelical definition. Statistics New Zealand, (2006), "QuickStats about Culture and Identity," http://www.stats.govt.nz/Census/2006CensusHomePage/QuickStats/quickstats-about-a-subject/cultureand-identity/religious-affiliation.aspx (accessed 2 June, 2010).

${ }^{27}$ Pamela D. H. Cochran, Evangelical Feminism: A history. (New York, London: New York University Press, 2005), 9.
} 
evangelicalism was born after World War II among a group of Protestant believers who subscribed to the basic doctrines of fundamentalism but rejected its lack of theological sophistication. ${ }^{28}$ The reformers hoped to broaden fundamentalism's evangelistic appeal and return to its revivalist roots. They maintained a high view of biblical authority, substitutionary atonement, Jesus’ bodily resurrection, the second coming and the need for a personal salvation experience. ${ }^{29}$ A significant change that evangelicals made to achieve their goals was to use modern theological methods such as some higher criticism. ${ }^{30}$

Evangelicalism has no formal constitutional guidelines for faith and for practice. It is better known for its individualism than its unity. The definition of evangelicalism which best represents the motivation for this research is derived from Mark Shibley, who outlines specific characteristics that refer to evangelicals as a group of believers who have had a born again or conversion experience resulting in a personal relationship with Jesus Christ, accept the full authority of the Bible in matters of everyday life and are committed to spreading the gospel by bearing public witness to their faith. ${ }^{31}$ What makes evangelicals distinctive is that they span a wide spectrum of Christian religions, cultures and lifestyles as a non-denominational faith with varying degrees of conservative attitudes to liberal positions. For the purposes of this research, women in New Zealand who identify as Pentecostal are included among evangelicals because the definition of evangelical above is a broad category in which Pentecostals are included.

\footnotetext{
${ }^{28}$ Pamela D. H. Cochran, Evangelical Feminism: A history. (New York, London: New York University Press, 2005), 6.

${ }^{29}$ Ibid.

${ }^{30}$ Ibid.

${ }^{31}$ Mark A. Shibley, "Contemporary Evangelicals: Born-Again and World Affirming," Annals of the American Academy of Political and Social Science 558 (1998): 67-87.
} 
It is imperative to this definition to distinguish between fundamentalism and evangelicalism, especially in the New Zealand context. The women in this research are not fundamentalists and indeed many of them distance themselves from the conservative fundamentalist movement that is present in, for example, the United States. Members of the faith communities studied might be described as 'worldly' conservatives because they are involved in, and encourage involvement in, secular society. Quoted by many women was the saying, "we are in, but not of, the world", paraphrasing John $17: 13-16 .^{32}$ It was this notion of being in the secular world that separated modern evangelicalism, as represented by the National Association of Evangelicals, from fundamentalist Protestantism. ${ }^{33}$

Although there seems to be significant contradiction between evangelicalism and feminism, it is important to provide definitions to allow for both terms to be accurately examined for the purposes of this research. Therefore the most basic definition of feminism in modern society is that feminism is invariably linked to the women's movement and the attempt to advance the social role of women. As such, it is associated with two basic beliefs: that women are disadvantaged because of their sex, and that this disadvantage can and should be overthrown. ${ }^{34}$ Nevertheless, feminism has also been characterised by a number of views and positions which have had positive and negative implications. The women's movement has pursued goals that range from the achievement of women's suffrage and the establishment of equal access to education to campaigns supporting the legalisation of abortion and abolition of pornography. The first text of modern feminism is usually taken to be Mary Wollstonecraft's $A$

\footnotetext{
32 John 17:13-16. In this essay, all biblical quotations are from the New Revised Standard Version (London: HarperCollins Publishers, 1989).

${ }^{33}$ George M. Marsden, Reforming Fundamentalism: Fuller Seminary and the New Evangelicalism (Grand Rapids, Michigan: Wm. B. Eerdmans Publishing, 1995), 10.

${ }^{34}$ Andrew Heywood, Political Ideologies: An Introduction (New York: Palgrave Macmillan, 2003), 240.
} 
Vindication of the Rights of Women, written against the backdrop of the French Revolution. ${ }^{35}$ It is easy to dismiss feminism as being characterised more by disagreement than agreement; however, a range of 'common ground' themes can be identified within feminism. The most important for the definition of feminism in this research are the following: the public and private divide, patriarchy, sex and gender, equality and difference. In today's society feminism is less radical, as the militant and revolutionary wing of the movement has been marginalised. It is the radical feminist movement which many evangelicals identify feminism with and impenetrable barriers remain which, if removed, would allow the two movements to share experiences. The feminist literature demonstrated signs of revisionism through Friedan's The Second Stage and Greer's Sex and Destiny, both of which celebrated the importance of childbearing and motherhood. ${ }^{36}$

It is necessary to define two key terms within evangelical scholarship, complementarian and egalitarian, because they have specific meanings in evangelical discourse and are relevant to the discussion and analysis. The terms are the foundation for the debate over traditional gender roles in evangelicalism.

\section{The Complementarian Argument}

The complementarian position advocates a distinct role between men and women where the man has ultimate headship, authority and responsibility in marriage. Complementarians argue that this distinction between male and female roles stems from

\footnotetext{
${ }^{35}$ Mary Wollstonecraft, A Vindication of the Rights of Women (New York: Cosimo, 2008).

${ }^{36}$ Betty Friedan, The Second Stage (Cambridge, Mass.: Harvard University Press, 1998); Germaine Greer, Sex and Destiny: The Politics of Human Fertility (London: Secker and Warburg, 1984).
} 
the "created order" that has existed since the Garden of Eden. ${ }^{37}$ The Council of Biblical Manhood and Womanhood promotes this stance, articulated in The Danvers Statement, the official statement of the complementarian Christian view of gender roles. ${ }^{38} \mathrm{~A}$ number of authors take the view that evangelical feminism is a challenge and this forces the larger culture to move swiftly against biblical authority. Wayne Grudem argues that evangelical feminism now represents one of the greatest dangers to the continued orthodoxy of the evangelical movement. He states, "I am concerned that evangelical feminism (also known as "egalitarianism") has become a new path by which evangelicals are being drawn into theological liberalism”. ${ }^{39}$ Their issue with the complementarian position is that it considers different patterns of argument put forth by evangelical feminists and demonstrates that every one of them either contradicts or compromises the authority of Scripture. ${ }^{40}$ This view, however, is arguable as the following research investigates evangelical women who have a robust faith and some of whom identify with feminist values. Interestingly, Steven Tracy identifies as a 'nonegalitarian' because he disagrees with egalitarians by recognising legitimate authority in the marriage relationship. Tracy correspondingly disagrees with complementarians for not thinking carefully enough about how to protect women from the sinful abuses of authority in marriage. ${ }^{41}$ Although Tracy's ideas are conservative in nature, he takes a unique approach in exploring the interplay between authority and submission in

\footnotetext{
${ }^{37}$ C. W. Colaner and S. C. Warner, "The Effect of Egalitarian and Complementarian Gender Role Attitudes on Career Aspirations in Evangelical Female Undergraduate College Students," Journal of Psychology and Theology 33 (2005): 224-9.

38 "Core Beliefs: The Danvers Statement on Biblical Manhood and Womanhood," (1987), www.cbmw.org/Danvers (accessed 25 April, 2010).

${ }^{39}$ Wayne Grudem, Evangelical Feminism: A New Path to Liberalism? (Wheaton, Illinois: Crossway Books, 2006), 15.

40 Ibid.

${ }^{41}$ Steven R. Tracy, "What Does 'Submit in Everything' Really Mean? The Nature and Scope of Marital Submission,” TRINJ 29 (2008): 285-312.
} 
complex marital matters. His perspectives shed light on some of the differing views of the women interviewed for this research.

\section{The Egalitarian Position}

Although a number of studies have demonstrated that evangelical women are more likely than other women to adopt anti-feminist positions, recent research suggests that there might be substantial support among evangelicals for certain feminist positions. The opposite end of the continuum, egalitarianism, is a position which promotes gender equality in evangelical Christian circles by claiming the verse "There is neither male nor female, for you are all one in Christ Jesus” (Galatians 3:28). This is the position held by the organisation Christians for Biblical Equality which argues that men and women are to together fulfil the 'creation' mandate given in Genesis. ${ }^{42}$ Using data from the 1984 American National Election study, Clyde Wilcox and Elizabeth Adell Cook find that evangelical women are indeed more anti-feminist than other women; however, a sizable minority take feminist positions on a number of issues. Approximately one in six can be classified as having a politicised feminist consciousness, while an additional one in four are potential converts to the feminist cause. ${ }^{43}$ However, these potential feminists display a reasonably negative attitude toward the feminist movement. This is due in part to the association made by many evangelical women that the women's movement promotes lesbian rights and abortion. Furthermore Elaine Storkey offers a rationale for biblical feminism, arguing that there is no difference in the role of men and women. There is complete equality in husband and wife relationships. She emphasises that the traditional

\footnotetext{
42 "Men, Women and Biblical Equality" Christians for Biblical Equality 1989, in Colleen Warner Colaner and Susan C. Warner, "The Effect of Egalitarian and Complementarian Gender Role Attitudes on Career Aspirations in Evangelical Female Undergraduate College Students,” Journal of Psychology and Theology 1 (2005): 225.

${ }^{43}$ Elizabeth Adell Cook and Clyde Wilcox, "Feminism and the Gender Gap - A Second Look," The Journal of Politics 53:4 (1991): 1111-1122.
} 
roles of the male in the workplace and the female in the home is not sealed with an indelible scriptural stamp and emphasises that jointly shared working and domestic roles are equally Christian. ${ }^{44}$

\section{Statement of the Problem}

Global evangelicalism is a multi-faceted reality. Whatever may have once been the situation, evangelicalism today embraces a number of groups with diverse features and emphases. Teenagers are being born again at Christian rock concerts and, in the United States, the conservative Christian lobby group Concerned Women for America has more members than the feminist National Organisation for Women. ${ }^{45}$ Conversion, or being 'born again', is a significant experience for every evangelical. Whether it occurs at a specific time and place or whether it is a gradual process, conversion is the key defining aspect of every evangelical. Conversion rates for women are high - there are significantly more female congregants than male. This is not reflected in church leadership, however, where women are either prohibited from rising to leadership or are severely under-represented within leadership circles. Women are obviously attracted to the commitment of evangelical faith - are they fulfilled as women of faith? There is an apparent tension between the sacred and secular worlds which stems from a fundamental disagreement in the church - the equality of women and the acceptance of feminist values. Why are evangelical congregations filled with women in a post-modern society? What inspires women to be both women of faith and women in the secular

\footnotetext{
${ }^{44}$ Elaine Storkey, What's Right with Feminism? (London: SPCK, 1985).

45 Christel Manning, God Gave Us the Right: Conservative Catholic, Evangelical Protestant and Orthodox Jewish Women Grapple with Feminism (New Brunswick, N.J.: Rutgers University Press, 1999), 3.
} 
societal context is the freedom with which evangelical women may have individual views and do not have an enforced doctrine as outlined by the church that they have to uphold. Evangelical women in New Zealand express autonomy and individuality within the church community. This area of research has failed to be investigated in a New Zealand context and therefore the question remains: are evangelical women in New Zealand combating the contradictions between feminism and evangelicalism? Evangelical women are different from those in other religious denominations - faith for them is existential not merely conceptual. Evangelical women were chosen to be studied in the place of other religious women because evangelicalism's focus on individualism within community most clearly highlights how women can live in two separate worlds. It illustrates how the challenges and contradictions arise in evangelicalism more than in other denominations.

Tensions exist between evangelical women's commitment to the religious world and simultaneously to secular society. Women fail in the tension to be in secular society but not of it. This is not necessarily a negative portrayal of evangelical women - it merely shows how secular society has influenced them in such a way that they are adapting to cultural change. These changes have affected the role of women both in the home and in society. These changes are reflected in the Pew Research Centre's findings that women performed higher than men with regards to education and earnings growth, leading to 'gender role reversals' when concerning marriage’s economic benefits. The percentage of women earning more than their husbands increased to 22 percent in 2007 from 4 percent in $1970 .{ }^{46}$ Of the women participating in this research, many were living in two

\footnotetext{
${ }^{46}$ Richard Fry and D’Vera Cohn, "Pew Research Centre: New Economics of Marriage: The Rise of Wives," (2010). http://pewresearch.org/pubs/1466/economics-marriage-rise-of-wives?src=prclatest\&proj=peoplepress (accessed 2 January, 2011).
} 
apparently separate worlds. They attended church on Sunday and Lifegroup on Wednesday and their faith was significantly important. But on the other hand, they had secular employment and secular friendships which seemed separate from their religiosity. How separate really are these worlds? The perception is that they are polar opposites therefore this research will investigate the prominent gap between them. 


\section{CHAPTER TWO}

\section{REVIEW OF THE LITERATURE}

All women are brought up from the very earliest years in the belief that their ideal of character is the very opposite to that of men; not self will, and government by self-control, but submission, and yielding to the control of others. All the moralities tell them that it is the duty of women, and all the current sentimentalities that it is their nature, to live for others; to make complete abnegation of themselves, and to have no life but in their affections. ${ }^{47}$

\section{Introduction}

Over the last decade, evangelical feminism has surged into evangelical scholarship. Christian women are highlighting the importance of the feminine and the gifts that women provide to worship. Not only are there debates about religion within feminist circles, but polemic debates regarding feminism in evangelical organisations have also divided institutions such as the Evangelical Women's Caucus into two groups: the moderate Christians for Biblical Equality and the more liberal Evangelical and Ecumenical Women's Caucus. Similarly, history demonstrates a sustained feminist critique of religion because of its oppression of women. Evangelicalism's social conservatism is rooted in patriarchy and focuses on the family as the sacred foundation of society and social order. ${ }^{48}$ Many feminists, such as those studied for Kristin Aune's

\footnotetext{
${ }^{47}$ John Stuart Mill, The Subjection of Women (New York: D. Appleton \& Co., 1869), $26-27$.

${ }^{48}$ Christina Wolbrecht, The Politics of Women's Rights: Parties, Positions and Change (Princeton, N.J.: Princeton University Press: 2000), 40; Kristin Aune, "Much Less Religious, A Little More Spiritual: The Religious and Spiritual Views of Third-Wave Feminists in the UK,” Feminist Review 97 (2011): 32-55.
} 
research on the religious views of feminists in the United Kingdom, do not identify as religious themselves - which raises a question regarding whether you have to be secular to be a feminist. ${ }^{49}$ The point of difference among the evangelical women in this research is that they place importance on both feminism and secularity which is a key finding.

New Zealand has experienced an evangelistic revival with significant growth in the evangelical institutions. Women comprise a large part of this development. One interviewee said that women made up $70 \%$ of her church's congregation; therefore it is more necessary than ever to research this phenomenon. This raises questions about how women manage this apparent marginalisation while at the same time living as liberated women in a secular society. Whether evangelical women identify with feminism as a symbol for liberal society is fundamental to the way in which women interact with religion in today's society.

The exploration of feminism as part of the identity of evangelical women is a critical study. Currently there is no literature that examines the role of feminism and liberal theory in the lives of evangelical women in New Zealand. Whether evangelical women are combating the contradictions between feminism and evangelicalism, and whether the two can be compatible, has not been researched in the New Zealand context. This situation of insufficient data is primarily due to the dominance of literature in countries such as the United States and the lack of focus on evangelical women in liberal society in New Zealand. As evangelicalism continues to expand globally, the study of how women manage their faith within secular liberal society is becoming more relevant and important in today's context - and especially in New Zealand. It is important to understand how feminism, as a symbol of secular liberalism, is significant and to Third-Wave Feminists in the UK,” Feminist Review 97 (2011): 32-55. 
ascertain how evangelical women negotiate the often-conflicting demands and rewards of their membership in their religious community and the larger society. The theme of the research, 'obligation versus liberation', illuminates and attempts to make sense of the conflicts evangelical women face. There is a need for a significant contribution to contemporary scholarship on the role of evangelical women in their faith and in wider New Zealand society. Not only will the research address a void in current scholarship, but it will build on influential studies from around the world to emphasise the position of evangelical women in the context of New Zealand society.

The literature review will address three areas related to evangelical women and the ways in which they negotiate the conflicts that come with living in a secular society. The first section will address research related to the evangelical movement globally how the movement began, the development of sociological research and the integration of feminism with evangelicalism. The second section will focus on the study of the evangelical movement in New Zealand, highlighting Christianity's history, women in mission in early New Zealand and the rise of Pentecostalism. Finally, the third section will discuss research related to feminism in New Zealand, looking at three influential feminist writers.

\section{Literature Review}

Studies have tended to focus on three main areas when looking at evangelicalism and women - the account of evangelicalism's history, the way in which religious traditions limit women's life opportunities and the ways in which women are reinterpreting their traditions as a source of empowerment. Within this literature there is consideration of a 
range of themes, from the historical accounts of global evangelicalism to the position of feminism in New Zealand society. The scholarship is not only significant in its field the chosen publications are relevant and have contributed to the foundations and understanding of this research. Unfortunately there is a significant amount of literature relevant to evangelical women that could not be included in this literature review as the range of literature is so vast that it cannot be condensed in to one literature review. ${ }^{50}$ However, a selection of literature has been chosen that will be the most beneficial in terms of understanding the key themes in this research.

\section{Global Evangelicalism - A Multi-Faceted Reality}

For decades scholars have debated the meanings of evangelicalism. It is a distinct and somewhat difficult phenomenon that many have attempted to define. Furthermore there have been similar debates to distinguish evangelicalism from fundamentalism, making the two recognisably dissimilar. In 1991 George Marsden published a collection of his essays on the principle subjects of his expertise entitled Understanding Fundamentalism and Evangelicalism. The purpose of Marsden's historical study was to inform and shape the way that individuals see evangelicalism and fundamentalism and to make a distinction between the two movements. ${ }^{51}$ These two motivations are significant as Marsden deconstructs the history of American fundamentalism and evangelicalism, providing a distinction between the two movements that was lacking in terms of clarity prior to his study. The historical overview of the book was particularly helpful in the development and understanding of the distinction. Many women interviewed for this study made a point of stating that they were different from the adherents seen in

\footnotetext{
${ }^{50}$ See footnote 54 for examples of noteworthy literature.

${ }^{51}$ George M. Marsden, Understanding Fundamentalism and Evangelicalism (Grand Rapids, Michigan: Wm. B. Eerdmans Publishing Co., 1991).
} 
countries such as the United States. They made it clear that they recognised themselves as evangelicals, not as fundamentalists.

Marsden provides an historical overview from 1870 onwards of the distinct ideological division within American Protestantism that fuelled the fundamentalist movement. An internal branch of evangelicals, divided from mainstream Protestantism, were motivated to confront the power of the secular modern society. He highlights the growing dissatisfaction among conservative evangelical Protestants who saw their liberal counterparts as being consumed by modernist behaviours. This group of evangelicals appeared to sacrifice Christian belief and practice for academic and political correctness. Marsden highlights the complex relationship between fundamentalism and evangelicalism. ${ }^{52}$ Marsden’s definition of evangelicalism provides a beneficial starting point for this research as it has enabled context with details of the developing history behind the evangelical movement. As many academics find the definition of evangelicalism difficult to deconstruct, Marsden provides a simple yet robust definition which has set the benchmark for defining evangelicalism. ${ }^{53}$

Marsden's definition paved the way for further research to be conducted on fundamentalism and evangelicalism. ${ }^{54}$ Seven years later, a study based on women who

52 George M. Marsden, Understanding Fundamentalism and Evangelicalism (Grand Rapids, Michigan: Wm. B. Eerdmans Publishing Co., 1991), 2-3.

${ }^{53}$ For recent debates on the definition of evangelicalism, see Gerald McDermott, "Evangelicals Divided: Gerald McDermott Describes the Battle between Meliorists and Traditionists to Define Evangelicalism," First Things: A Monthly Journal of Religion and Public Life 212 (2011): 45.

${ }^{54}$ See Sally K. Gallagher, Evangelical Identity and Gendered Family Life (New Brunswick, N.J.: Rutgers University Press, 2003); R. Marie Griffith, God's Daughters: Evangelical Women and the Power of Submission (Berkeley: University of California Press, 1997); Julie J. Ingersoll, Evangelical Christian Women: War Stories in the Gender Battles (New York: New York University Press, 2003); Christel Manning, God Gave Us the Right: Conservative Catholic, Evangelical Protestant and Orthodox Jewish Women Grapple with Feminism (New Brunswick, N.J.: Rutgers University Press, 1999); Julie B. Miller, "Living it Out: Forming Future Feminists: Elisabeth Schussler Fiorenza, Conscientization, and the College Classroom,” Journal of Feminist Studies in Religion 25:1 (2009): 99; Sarojini Nadar and Cheryl 
are integral to the development and survival of Christian fundamentalist congregations across the United States presented a portrait of Christian fundamentalist women, rather than just a general overview. Brenda E. Brasher's Godly Women: Fundamentalism and Female Power reported research on the motivation for women to become actively involved with Christian fundamentalist congregations in the late twentieth century. Although fundamentalist congregations were not explored in this research, Brasher's study provides significant themes and patterns that can be compared with the results of this research and analysed accordingly. Brasher’s ethnography reveals the contradiction that fundamentalist women can be powerful people in a religious cosmos generally understood to be organised around their disempowerment. She states that "women's ministries thrive in Christian fundamentalist congregations because they perform a necessary role: they empower women”. ${ }^{55}$ This may be a crucial study as it contributes to the understanding of women in the context of New Zealand and how they negotiate the often conflicting demands in their daily life. Brasher was inspired by a desire to understand why women join and become actively involved with Christian fundamentalist congregations in the late twentieth century.

Her study took place in two fundamentalist Christian congregations in California. The participants included 47 women from Bay Chapel and Mount Olive. ${ }^{56}$ Brasher chose the initial participants through a snowball approach, however as she became increasingly familiar with the congregations, women approached her. Each woman took part in a semi-structured interview averaging two hours in length. According to congregational

Potgieter, "Living It Out: Liberated Through Submission? The Worthy Woman's Conference as a Case Study of Formenism,” Journal of Feminist Studies in Religion 26:2 (2010): 141-151.

${ }^{55}$ Brenda E. Brasher, Godly Women: Fundamentalism and Female Power (London: Rutgers University Press, 1998), 27.

${ }^{56}$ These are not the real names of the congregations; they were used to protect anonymity, so this research will retain the pseudonyms. 
surveys, 62 percent of those attending Mount Olive are between the ages of 26 and $45 .^{57}$ At Bay Chapel the figure is 72 percent. $^{58}$ There is a significant over-representation in the demographics of white women, of whom most are married. ${ }^{59}$ This is one limitation to Brasher's study that can affect the validity of results. It is understood and explained, however, that women attracted to fundamentalist congregations are predominantly white, educated and from medium to high socio-economic status. ${ }^{60}$ It is interesting to note that over half of the women interviewed converted to fundamentalism during a period of marital crisis. ${ }^{61}$ Sixty-two percent were engaged in wage-earning work.

Godly Women examines the context that sustains a growing subculture of American religious women. Brasher's research develops the themes from Betty DeBerg's historical analysis of American fundamentalism, entitled Ungodly Women: Gender and the First Wave of American Fundamentalism. DeBerg argued that the rhetoric of the first wave of fundamentalism in the early twentieth century was a direct response to advances in women's rights in mainstream secular society. ${ }^{62}$ Similarly, Brasher builds on Margaret Bendroth's work regarding the role of women in fundamentalist parachurch organisations. Brasher's study is intended to fill a gap in the research literature by examining how the social relations of women in fundamentalist congregations provide fulfilment within a life organised and articulated by men.

\footnotetext{
${ }^{57}$ Brenda E. Brasher, Godly Women: Fundamentalism and Female Power (London: Rutgers University Press, 1998), 127.

58 Ibid.

59 Ibid., 15. At Mount Olive, 65 percent of the membership is white, 28 percent is Mexican-American, 3 percent is Asian-American, 2 percent is African-American, and 2 percent is other. Sixty percent of women are married (128). At Bay Chapel 84 percent of the membership is white, 8 percent is MexicanAmerican, 4 percent is Asian-American, 2 percent is African-American, and 2 percent is other (16). Seventy-two percent of women are married (128).

${ }^{60}$ Brenda E. Brasher, Ibid., 8.

${ }^{61}$ Ibid., 128.

62 Paula D. Dempsey, "Review: Godly Women: Fundamentalism and Female Power by Brenda E. Brasher,” Sociology of Religion 60:2 (1999): 204.
} 
Although it may be assumed that fundamentalist women struggle to exercise power and authority in their congregations and homes, Brasher highlights gender as a critical aspect of identity. She demonstrates that women have created a realm of their own, a world that can “accommodate the pressure of fundamentalist women's changing needs while allowing the congregation to present itself as a strict, intransient institution”. ${ }^{63}$ Significantly, this aids and empowers women in their relationships and their life direction. Thus the women from Bay Chapel and Mount Olive develop unique social relationships that act as a resource for those facing crisis. Brasher reveals and deconstructs this paradox and provides a new insight on the ideas and faith experiences of fundamentalist women, illustrating that the religiosity they develop is not as disempowering as some may assume. Thus fundamentalist women can and do exercise considerable power among other women.

As Brasher highlights the importance of godly women in her empirical research, focus similarly turns to the role of feminism in evangelical theology. There is a shift from Marsden's definition of fundamentalism to his definition of evangelicalism which acts as the foundation for Pamela Cochran's definition of evangelical feminism. Cochran's Evangelical Feminism is not the first work to be written on the subject; however, it is significant for it provides a meticulous history of two influential organisations which catapulted the evangelical feminist movement into the public sphere. Cochran focuses on the Evangelical Women's Caucus (EWC) and Christians for Biblical Equality (CBE), which she describes as representing the "progressive" and "traditionalist" ends of the evangelical feminist spectrum. In her study, Cochran filled a primary gap in evangelical literature which previous scholars had failed to address. No study at the

\footnotetext{
${ }^{63}$ Brenda E. Brasher, Godly Women: Fundamentalism and Female Power (London: Rutgers University Press, 1998), 168.
} 
time of publication had analysed the history and theology of contemporary evangelical feminists to ascertain the impact they had made and how they might have illuminated the situation of contemporary American religion. ${ }^{64}$

At the centre of evangelical feminism are two pre-eminent organisations - the Evangelical Women's Caucus (EWC) and Christians for Biblical Equality (CBE). Cochran studies the individuals who have represented the theologies of the organisations. The book begins by giving a detailed account of the intellectual history of evangelical feminist theology focusing on biblical authority. Cochran identifies the history of its leading institutions and their social agendas. She sets evangelical feminism in the context of American evangelical religion and the secular women's movement. Her insight into the secular feminist movement and how it provided a model for evangelical feminism to develop from, and subsequently shift away from its secular counterpart, provides fundamental links with this research in terms of understanding the feminist movement in New Zealand and whether contemporary women identify with it. ${ }^{65}$ This research addresses the formations of a feminist identity for evangelical women and the ideological conflicts involved in pursuing such feminist theology. This is directly linked with Cochran's argument that evangelicals were like their secular counterparts - they "sought to mend the split between the public role of men and the private sphere of women”, ${ }^{66}$ This often meant working alongside secular feminist organisations, such as the National Organisation for Women, toward mutual ends, for example, the ratification of the Equal Rights' Amendment. ${ }^{67}$ The secular feminist movement was moving beyond mere equality of opportunity, thus causing conflict

\footnotetext{
${ }^{64}$ Pamela D. H. Cochran, Evangelical Feminism: A history. (New York, London: New York University Press, 2005), 9.

${ }^{65}$ Ibid., 75.

${ }^{66}$ Ibid., 74.

${ }^{67}$ Pamela D. H. Cochran, Ibid., 75.
} 
between the secular and evangelical feminist alignment. That conflict is the crux of this research. Cochran provides a significant detail which can be compared to the conflict investigated between evangelical women in New Zealand and their struggle to negotiate the ever-increasing contradictions of living within a secular world - adopting feminism as a means of gaining control over secular liberalism.

The divide between EWC and CBE provides the starting point for understanding the theological differences between both organisations. The conservative-liberal divide is a significant theme, one that has been explored throughout this research. Although both organisations are egalitarian, the divide between 'liberal' and 'conservative' led this study to discover alternative research parallels such as the egalitarian and complementarian divide. The debates surrounding this divide have been significant in shaping the contemporary literature on evangelical feminism, as most scholarship either takes a stance on the issue or explores the divide. One limitation to Cochran's work is that her chronological references are significantly disproportionate, mainly from the 1970's and 1980's. Although she is documenting information from the history of this period, her work may have benefited from more contemporary sources to reinforce the significance of her publication today. Cochran's conclusions provide a distinction between biblical feminism and the rest of evangelicalism because of its social progressivism on the issue of women's equality, and at the same time it distinguishes itself from secular feminism by its insistence on the centrality of biblical authority in the issue of church and society. ${ }^{68}$ Cochran has effectively traced the development of

\footnotetext{
${ }^{68}$ Pamela D. H. Cochran, Evangelical Feminism: A history. (New York, London: New York University Press, 2005), 9.
} 
evangelical feminism, focusing on its theology and view of biblical authority and on its leading organisations and their social agendas. ${ }^{69}$

As evangelical scholarship has grown, the theme of gender has developed significantly. What is evident from examples, such as the divide between EWC and CBE and the separation of evangelicalism from its more fundamentalist counterpart, is that evangelical feminism is a divisive issue. It reflects the changing nature of religion evangelicalism is adapting with modern society, thus causing conflict within some evangelical circles. By engaging with the secular world, evangelicalism is a liberalising tradition culturally and theologically. It is the combination of both secular and religious which enables evangelicalism in New Zealand to develop and grow. Evangelical women in New Zealand must now negotiate living in a secular world as a reality as well as being women of faith. They must deal with added tension compared with secular women, as evangelicals are faced with living in two distinct, and at times conflicting, worlds. Evangelical women who want to be relevant in today's society must immerse themselves in secular culture through work, friends or family. Thus the challenge of living in two worlds becomes evident - it is this significant contradiction that evangelical women have to negotiate.

\section{The Evangelical Scene in New Zealand}

Scholarship focussed on the New Zealand evangelical movement is less extensive compared with its counterparts in the United States and Britain. While piecemeal histories can be found from specific churches, the availability of reliable, scholarly publications is limited. There are, however, some notable exceptions - from authors

\footnotetext{
${ }^{69}$ Pamela D. H. Cochran, Evangelical Feminism: A history. (New York, London: New York University Press, 2005), 190.
} 
who have contributed significantly to the history of Christianity in New Zealand, to those who have provided an historical insight into women and religion throughout New Zealand's history.

Brett Knowles focuses on New Zealand Pentecostalism and the emergence of New Life Churches. His book The New Zealand Pentecostal Movement: The New Life Churches of New Zealand from 1946 to 1979 records an oral history of the New Life Churches. Based on interviews with key members of the movement, Knowles traces the development of the New Life Churches in the 1940's and the movement's subsequent growth to become one of the largest Pentecostal bodies in New Zealand by the 1970's. He examines the ways in which the movement's original revivalism became linked with moralist concerns and with the application of political pressure for social change. A secondary avenue of enquiry is the way in which the New Life Churches and the emerging New Zealand Charismatic movement had reciprocal effects.

What is significant about Knowles' work is that it spans a period of substantial growth of Pentecostal institutions. Leaders from the New Life Churches such as Peter Morrow were instrumental in developing the awareness of the Pentecostal movement in New Zealand. Furthermore, the addition of Charismatic Christianity gave considerable growth to the New Life Churches and contributed to the easing of the previously stringent religiosity. ${ }^{70}$ Similarly, the growth is attributed to events such as missionaries visiting from the Bethel Temple in Seattle, Washington. The missionaries brought a fresh dynamism with them and new doctrinal emphasis on the name of Jesus in the

\footnotetext{
${ }^{70}$ Stephen Fogarty, "Review: The History of a New Zealand Pentecostal Movement: The New Life Churches of New Zealand from 1946 to 1979 by Brett Knowles,” The Journal of the Society for Pentecostal Studies 23:2 (2001): 318-319.
} 
baptismal formula, which was the beginning of a division within Pentecostal circles. ${ }^{71}$ Although this research is investigating evangelicalism, some forms of Pentecostalism are identified under the evangelical umbrella. Many churches in New Zealand identify themselves as both evangelical and pentecostal. Similarly there were women interviewed for the purposes of this research who stated demographically that they were pentecostal, yet still identified themselves as evangelicals and attended evangelical churches. Knowles' history has supported this research in that it documents themes of the Pentecostal movement that occurred within the broader evangelical environment. This provides significant historical background information on the subject and has allowed for an enhanced understanding of the New Zealand context to be established.

One limitation in Knowles' work is that as he recounts the history of Pentecostalism in New Zealand, he writes as an insider with pentecostal worldview. Knowles has had significant involvement in the New Life Church, including positions of pastor, missionary and Bible School Principal. ${ }^{72}$ This can cause conflicts of interest as the introduction of bias is possible which can affect the validity of research. Although he is involved with the movement himself and he has almost unrestricted access to key members of the movement, Knowles writes from the perspective of his pentecostal commitment while writing an evaluative account of its history which can significantly increase the level of bias in his publications.

When conducting research on evangelicalism in New Zealand it is important to rely on publications that have shaped the literature on the subject. Brett Knowles achieved this

\footnotetext{
${ }^{71}$ Brett Knowles, The History of a New Zealand Pentecostal Movement: The New Life Churches of New Zealand from 1946 to 1979 (Dunedin, N.Z.: Third Millennium Pub., 1999), 19.

${ }^{72}$ Stephen Fogarty, "Review: The History of a New Zealand Pentecostal Movement: The New Life Churches of New Zealand from 1946 to 1979 by Brett Knowles,” The Journal of the Society for Pentecostal Studies 23:2 (2001): 318-319.
} 
and so did Cathy Ross with her investigative research on the metaphor of 'separate spheres' for women. She examines a case study of two New Zealand Church Missionary Society (CMS) missionary wives - Elizabeth Colenso and Kate Hadfield. In Separate Spheres or Shared Dominions? Ross argues that 'separate spheres' denotes the marginalisation of women from mainstream society. It is here that the home transforms into a fundamental place of activity for women. Ross examines how this played out in the nineteenth century and how an evangelical worldview reinforced it.

Ross defines ‘separate spheres' as a metaphor used to analyse women’s role in history and society. It has been used to describe the marginalisation of women into their own separate sphere, distinct from the sphere of men, for example, 'public and private'. She argues that evangelical theology reinforced the idea of 'separate spheres' and provides valid evidence to demonstrate this. Ross gives an example from the Rev. Henry Venn’s publication The Complete Duty of Man, which was commonly known as “a sort of manifesto of the evangelical views". ${ }^{73}$ The document instructed a wife that it was her duty to obey the will of her husband. He wrote, "It is therefore nothing less than an open resistance to the ordinance of God; it is nothing less than a proud and self-exalting contempt of the word of God, in a wife to affect to rule, or to refuse to submit to the authority of her husband." ${ }^{74}$ Ross’ example illustrates her argument that evangelicalism reinforced a separate sphere for women - it was this view that set the standard for the evangelical understanding of womanhood. This argument contributes to the context regarding the expectation that women were not to have the same roles as men - that they were confined to the domestic context. Feminist publications tend to overlook the

\footnotetext{
${ }^{73}$ Cathy Ross, “Separate Spheres or Shared Dominions?” Transformation: An International Journal of Holistic Mission Studies 23 (2008): 228-235.

${ }^{74}$ Rev. Henry Venn quoted in Cathy Ross, "Separate Spheres or Shared Dominions?” Transformation: An International Journal of Holistic Mission Studies 23 (2008): 228-235.
} 
fact that through men, who were holding the leadership positions, the conservative stance had been passed down through many subsequent generations. It took women such as the missionary wives Elizabeth Colenso and Kate Hadfield, whose notion of womanhood was influenced by the 'separate sphere', to interpret their worldview differently and begin a process of attitudinal change. ${ }^{75}$

Ross outlines the histories of Elizabeth Colenso and Kate Hadfield - both born into New Zealand missionary families. The account describes the lives of the two pioneering women. Elizabeth was running her own school at nineteen years of age. Furthermore she did it without any recognition from the CMS. She survived natural disasters, continuing to manage her home and start schools around Ahuriri, New Zealand. She ultimately left her husband William Colenso, which for a woman of evangelical heritage was a serious breach of a commitment. Kate, too, was an accomplished teacher at the age of twenty. She was ultimately made the first Vice-President of the Girls’ Friendly Society (GFS), an organisation founded by women, serving women and run by women. She made significant journeys for mission with her husband, including being the first white woman to make the horrendous overland trip from Auckland to Otaki. These are recollections of women who lived and worked in New Zealand and pushed many boundaries. The significance of these stories is that they encapsulate what living as an evangelical woman was like historically in New Zealand, as well as demonstrate the different interpretations the women made of their faith. These women were really

\footnotetext{
${ }^{75}$ For debates on evangelical social issues and change see Ralph Brown, "Evangelical Social Thought," The Journal of Ecclesiastical History 60:1 (2009): 126 -136; Boyd Hilton, "Evangelical Social Attitudes: A Reply to Ralph Brown,” The Journal of Ecclesiastical History 60:1 (2009): 119 -125; Donald E. Miller, "Hope Chapel: Revisioning the Foursquare Gospel," in The Annual Meeting of the Society for the Scientific Study of Religion (Washington, DC., 1992); Mark A. Shibley, "Contemporary Evangelicals: Born-Again and World Affirming," Annals of the American Academy of Political and Social Science 558 (1998): 67-87.
} 
evangelical feminists as they would not be held back in the missionary field just because they were women.

Ross concludes that the ideology of 'separate spheres' led to ambiguity in establishing the role and identity of women within evangelicalism. It was clear that women were supposed to be subordinate; however, women such as Elizabeth Colenso and Kate Hadfield continued to have influence in their missionary field. Ross' comments on the apparent subordination of women and their practical influence align with a central motif throughout this research - male headship. Many women interviewed for this research showed overwhelming support for male headship in theory, but not necessarily in practice, following in the footsteps of Elizabeth and Kate.

The history of religion in New Zealand is institutionalised in culture. For a small and relatively new country, New Zealand has a colourful religious history which has been well documented. Authors such as Knowles and Ross have focused on a specific aspect of religious history, whereas Peter J. Lineham and Allan K. Davidson provide an expansive history of New Zealand religion and its movements in Transplanted Christianity. Their topics include the age of missions, church and state in European New Zealand before 1875, Christianity and the Māori, and New Zealand churches and society in three periods - 1875 to 1914 , from the onset of World War I to the close of World War II, and 1945 to 1985. While detailing all of the information in this publication is not within the scope of this research, it is important to highlight the significance of this compilation of documents and commentary. It illuminates a number of issues such as the struggle to transplant Christianity from settled societies in the Northern Hemisphere to a geographically remote colony in the Antipodes, the challenge to transcend the limitations of a colonial situation and to meet the religious needs of the 
people indigenous to the land, and the call for adjustment in order for the churches to remain viable in a changing society.

A theme of Transplanted Christianity, inseparable from this research, is social change in New Zealand, especially during the twentieth century. Two facets, in particular, align with this research. Firstly, Davidson and Lineham detail the new force of Pentecostal and charismatic movements which came in the 1960's. The authors describe the movement as intense, enthusiastic, emotional and experiential with its initial uniqueness perceived as divisive. ${ }^{76}$ However, once it began to penetrate the larger denominations, it seemed to have brought life back into both individuals and congregations. In a survey of Pentecostal/evangelical congregations today in New Zealand one will find again this 'life' lingering that was once injected back into the movement. While much has changed in the Pentecostal movement some aspects have remained the same. Pentecostalism continues to be metamorphic - a traditional religion adapting to modern culture.

Secondly, Davidson and Lineham discuss women in the church. They open their discussion with the statement, "Women were always crucial to the New Zealand church, both as the largest proportions of congregations and the most active church workers." This important first sentence emphasises women's role in the New Zealand Church. The authors continue to develop the history of women gaining leadership and respect in different denominations and provide a number of primary sources as evidence. For example the Report of the Special Committee on the Position of Women in the Church from the Presbyterian General Assembly in 1953 is included. It states that women have

\footnotetext{
${ }^{76}$ A. Davidson and P. Lineham, Transplanted Christianity (Palmerston North, N.Z.: Massey University; Department of History, 1994), Chapter 6, III.

${ }^{77}$ Ibid.
} 
shown themselves capable of entering all spheres of life and it is difficult to believe that the church is one exception. ${ }^{78}$ These comments are crucial to understanding women's involvement with religion historically in New Zealand. After years of being prohibited from leading, women were being recognised for their gifts and were being given opportunity to use them. Nevertheless, it was a world where religious women had to battle to get recognition for their gifts, which prompts interesting questions about today's situation. Do evangelical women in New Zealand today have the benefit of opportunity unlike their historical counterparts? There is certainly more choice and variety for women within evangelical churches, some of which can be attributed to feminism. Was feminism simply done for them?

Davidson and Lineham highlight extensive social change in New Zealand, a primary focus of their book. The authors document various Christian responses, touching a wide range of issues such as Pentecostalism and women's involvement in the church that are significant to the understanding of this phenomenon in the New Zealand context. The use of primary sources on each subject by Davidson and Lineham is extensive and this contributes to the historical setting. Davidson and Lineham cite both assessments and prognoses, but admit that recounting the past opens up a wide area for debate.

Evangelical women have two separate lives - one of secular liberation and one of obligation to their faith. Kate Hadfield and Elizabeth Colenso are examples of evangelical women who lived in two worlds. They ran schools, held leadership positions and were teachers. Colenso even left her husband, which was a serious taboo for evangelical women in that time and place. What is evident is that the evangelical

\footnotetext{
${ }^{78}$ A. Davidson and P. Lineham, "The Report of the Special Committee on the Position of Women in the Church from the Presbyterian General Assembly in 1953,” Transplanted Christianity (Palmerston North, N.Z.: Massey University, Department of History, 1994), Chapter 6, VIII.
} 
rhetoric these women lived by was far from their reality. On the one hand they were evangelical women in a separate sphere from men, but on the other hand they were independent leaders in their community. Another theme of this research is that of religious change and development. Religion's priority of belief and the secular commitment to individual rights are no longer in opposition - they complement each other. Evangelicalism in New Zealand has opted to grow on secular terms and is less hostile to liberal ideas such as tolerance and pluralism. Social change has inevitably facilitated religious change - these changes have enabled evangelical women to hold the positions that they do today. Society has influenced the adaptations evangelicalism has made to secular culture, which has encouraged evangelical women to live in both a secular and a religious world simultaneously. Ideal as this alliance between the secular and religious may sound, the reality allows contradictions to surface.

\section{New Zealand Feminist Theorists}

New Zealand has led the world in feminist theory and practice. ${ }^{79}$ It was the first country to provide universal women's suffrage in voting rights in a self-governing country in 1893. While the construction of 'women' as a political category was a significant achievement of the nineteenth century suffragists and second wave feminists, a debate emerged for the need to address differences among women. ${ }^{80}$ There has been a vast amount of literature, agendas and polemic opinions surrounding the feminist debate. The sheer magnitude of feminism theory in New Zealand competes with its social

\footnotetext{
${ }^{79}$ Wendy McElroy, "Feminism and Liberty,” Speech, the International Society for Individual Liberties New Zealand Conference, Rotorua, 2004; Sandra Coney, Stroppy Sheilas and Gutsy Girls: New Zealand Women of Dash and Daring (N.Z: Tandem Press, 1998); Sue Kedgley and Mary Varnham (eds.), Heading Nowhere in a Navy Blue Suit: and Other Tales from the Feminist Revolution (Wellington, N.Z.: Daphne Brasell Associates Press, 1993); Jennifer Jones, "When Women’s Rights Are Not Our Own," Muse Feminist Magazine, August 16, 2009, issue 4.

${ }^{80}$ Rosemary Du Plessis and Lynne Alice (eds.), Feminist Thought in Aotearoa /New Zealand: Differences and Connections (Auckland, N.Z.: Oxford University Press, 1998), xv; see also Judith Butler, Undoing Gender (London: Routledge, 2004).
} 
counterparts. Thus feminist scholarship in New Zealand has had, and continues to have, a major impact on the academic sphere. Three New Zealand feminist scholars have been chosen for review because they pioneered feminism in the 1970's and 1980's. Phillida Bunkle, Rosemary Du Plessis and Marilyn Waring were the foundational figures of second wave feminism in New Zealand and their scholarship set the precedents for future feminist movements.

Part of the historical element relevant to this research is the Temperance Movement. Temperance societies were the product of evangelical Christianity and similarly temperance societies were a spawning ground for feminism. Phillida Bunkle has made a significant contribution to the history of women in New Zealand. Her article The Origins of the Women's Movement in New Zealand: The Women's Christian Temperance Union 1885-1895 discusses the significance of the Women's Christian Temperance Union (WCTU) within its historical roots, promoting suffrage and effectively being the first organisation for women. ${ }^{81}$ Women joined the temperance movement to support women's rights - it was not purely to encourage a prohibition on alcohol. The New Zealand WCTU flourished and women flocked to meetings which educated women to "make good citizens of the boys, and useful women of the girls". ${ }^{82}$ Already we see here in Bunkle's work that the initial focus of the WCTU in New Zealand was women. Thus the favourite theme in the President's address was that "though we are a feeble band in ourselves, a people not strong, yet we shall be made more than conquerors through Christ who strengthens us”. ${ }^{83}$ Immediately the feminist threads of this Christian organisation are illustrated. Where this is significant is that the

\footnotetext{
${ }^{81}$ Phillida Bunkle, “The Origins of the Women's Movement in New Zealand: The Women's Christian Temperance Union 1885-1895," in Phillida Bunkle and Beryl Hughes (eds.), Women in New Zealand Society (Boston: Allen and Unwin, 1980), 54.

${ }^{82}$ Ibid., 58.

${ }^{83}$ Ibid.
} 
WCTU was diverse. Though fundamentally a Christian organisation, it attracted a wideranging audience. This is similar to feminism in New Zealand - it is attracting individuals from different cultures, religions and backgrounds and evangelical Christianity can be a part of the movement. This is because in today's society the audience is so broad and now more than ever there is the opportunity for feminism and evangelicalism to be compatible.

Women were taking a strong stance on protecting and safeguarding themselves and other women against family ruin, domestic violence and poverty, which forced many women into prostitution to survive. However, the movement was still rooted in evangelical Christianity. Secular women were joining an evangelical Christian movement as a way of tackling the utter vulnerability of women and children in these situations. This is how feminism started - which prompts questions of compatibility between evangelical and feminist ideals. Although today it is perceived that evangelical Christianity and feminism are polar opposites, originally the two movements were united through common goals. Bunkle depicts similarities between WCTU's views and the women's movement. She states that the WCTU thought that the training of girls to be sex objects and the contortion of women's bodies by corsets had robbed women of their physical freedom and right to self development. Bunkle uses an example of the WCTU's campaign to repeal the Contagious Diseases' Act which allowed for the inspection of prostitutes for sexually transmitted diseases. Women around New Zealand protested the law claiming it "violates the personal rights of women only, while the rights of men are jealously guarded and reserved”. ${ }^{84}$ This evidence supports Bunkle’s claims of similarity between the WCTU and the women's movement and provides

\footnotetext{
${ }^{84}$ Phillida Bunkle, "The Origins of the Women’s Movement in New Zealand: The Women’s Christian Temperance Union 1885-1895," in Phillida Bunkle and Beryl Hughes (eds.), Women in New Zealand Society (Boston: Allen and Unwin, 1980), 63.
} 
further validity to her research. Similarly the focal point once again is women's rights the motivation may have been evangelical, but in practice the movement intended to help women. This leads one to conjecture that perhaps feminism and evangelicalism are not such conflicting ideologies after all.

A number of other women achieved notoriety in feminist academia akin to that of Phillida Bunkle. One of those was Marilyn Waring. Waring was a New Zealand feminist, politician, an activist for women's rights, an author and an academic. A member of the New Zealand National Party, at 23 she became the youngest member of the New Zealand Parliament in 1975. Robin Morgan described Waring as breaking every stereotype in the political realm in New Zealand. ${ }^{85}$ Her independent, free-thinking and feminist opinions represented everything foreign to the conservative nature of both her own political party and much of mainstream New Zealand at the time. Her views put her on an unwavering collision course with her party's leadership. Waring had definite and liberal views on the status of women that she did not shy away from expressing. Indeed, her Women, Politics and Power collects a number of writings to inspire and educate women regarding feminism. Waring discusses the difficult role women must undertake in everyday life - she examines the oppressive situation women find themselves in and argues that women need survival skills and tactics in order to survive, let alone succeed, in political life. To highlight her argument, Waring uses headline examples of discrimination existent in New Zealand politics, surrounding the United Nations Decade for Women, as well as the arena of women and sport, with a view on nuclear disarmament to conclude her case.

\footnotetext{
${ }^{85}$ Robin Morgan, Foreword to Women, Politics and Power by Marilyn Waring (Wellington, N.Z.: Unwin, 1985), 1.
} 
In Women, Politics and Power, Waring's discussion of her nine years in New Zealand politics pulls no punches. Drawing on her varied experiences, she offers realistic advice to aspiring female leaders. She argues that women see problems as technical and not ideological and provides evidence to confirm this position. It is women who emphasise pragmatic cooperation and a public service approach and it is women who concentrate on community rather than on special interest needs. Politics for the male leader is more often a mere vehicle for personal ambition and career advancement. Unlike their male counterparts, political participation for women is likely to be a labour of love. ${ }^{86}$ Waring's perspectives on the roles of men and women in public life represent feminist views of the time, although in the context of today's society they may seem stereotypical of gender roles. Waring proposes the view that men and women are different political creatures as is supported by the evidence she presents that men and women entering political life do so with differing motivations. Her insight delves into the structural issues that define feminism. Waring explicitly portrays her feminism by arguing that women have a focus when they enter the political realm - women are not necessarily securing personal advancement or status, but seek development for others. She encapsulates the struggles and challenges she experienced as a woman in politics in the 1970's. She clearly articulates the complex questions that must be addressed when a woman is considering standing for Parliament, thus contributing to an understanding of women in politics in New Zealand at the heart of second wave feminism. Waring's snapshot of life as a female politician in the 1970's is a rare insight into the extra precautions they had to take in order to avoid disparagement. She recalls, "[R]unning against four middle-aged men with histories of substantial political involvement, I found, at age twenty-two, that I was the only candidate who hadn't had the time to make

${ }^{86}$ Marilyn Waring, Women, Politics and Power (Wellington, N.Z: Unwin, 1985), 34. 
enemies.” ${ }^{87}$ However Waring found that no matter what position of power a woman was in, the connections one had with other women were significantly more respected than those with their male counterparts. The silence of a shy woman is a wall of resistance. Passive resistance can be as strong as violent reaction - and it can be far more transformative. $^{88}$

"I hate to say it, but don't trust any men" is Waring's recommendation if a young woman is to succeed in politics. ${ }^{89}$ Her warning against male acquaintances communicates more than mere humour. It is an insightful reference that reiterates the context of a time when women were less respected by men and were thus treated so. In today's society, the concept of not trusting a man if you want to be involved in politics seems absurd - however in her context it was not. Waring is raising awareness of the view that men could have separate agendas when it came to women's empowerment. Waring's Women, Politics and Power contributes to a shared understanding of women and politics at a crucial time in New Zealand's history. She takes a firm feminist stance, advocating the facts of the significant difficulties and factors associated with being a woman in leadership on women's behalf. This is portrayed through her anecdotes of personal experience, for example, that "once inside the patriarchy, the rules are patriarchal, or you cannot move at all, bound in as you are by male constraints." 90 Waring's concluding comments elaborate on the lack of education politics gave her - it did not teach her anything she did not already know. She was already aware that women

\footnotetext{
${ }^{87}$ Marilyn Waring, Women, Politics and Power (Wellington, N.Z: Unwin, 1985), 36.

${ }^{88}$ Ibid., 33.

89 Ibid., 45.

${ }^{90}$ Marilyn Waring, Ibid., 33.
} 
are wonderful, clever, intelligent, witty, emotional, supportive, hilarious - “do you want me to go on?" 91

Another important feminist theorist in New Zealand is Rosemary Du Plessis. Like Bunkle and Waring, Du Plessis had a passionate interest in women and political life in New Zealand. Her major interests are in women's paid and unpaid work and state policy. Women's employment is of interest to this research, as many women interviewed for the study regarded pay equity and equal job opportunity between men and women as an extremely important requirement in New Zealand society. Du Plessis’ article Stating the Contradictions: the Case of Women's Employment argues that contradictions in state policy in New Zealand with respect to women mirror the ambivalent relationship between feminists and the state. ${ }^{92}$ She investigates the policies which governments embark on to improve the situation of women in some respects, but which fundamentally undermine it in others. The policy focus is on women and New Zealand employment in the late 1980's and early 1990's.

Du Plessis uses a case study of the Fourth Labour Government to exemplify unevenness and contradiction. She argues that its response to meet the claims of many different groups with contrasting agendas and opinions led to altered gender outcomes. For example, the Labour Party set up a Working Party on Equal Pay in 1988 and responded to its recommendations by introducing the Employment Equity Bill in 1989. It legislated for equal opportunities for a variety of disadvantaged groups, including women. The outcome was the Employment Equity Act 1990, which was shaped by a commitment to reduce state intervention in industrial relations. As a consequence of

\footnotetext{
${ }^{91}$ Marilyn Waring, Women, Politics and Power (Wellington, N.Z: Unwin, 1985), 36.

${ }^{92}$ Rosemary Du Plessis, "Stating the Contradictions: The Case of Women's Employment” in Rosemary Du Plessis and Lynne Alice (eds.), Feminist Thought in Aotearoa/New Zealand: Differences and Connections (Auckland, N.Z.: Oxford University Press, 1998), 209.
} 
this, the state would not require employers to increase the wages for a womendominated job, even if the Employment Equity Commission found that the job required the same level of skill and responsibility as a male-dominated job with higher wages. ${ }^{93}$ The outcome was similar to the policies of the Labour Government, which was committed to reducing state intervention in the labour market. Du Plessis argues that the Employment Equity Act appeared to contradict this: "in fact, the Act was a compromise between non-interference and intervention”. ${ }^{94}$

The importance of understanding 'feminist' policies such as the Employment Equity Act 1990 lies in whether they follow through to achieve the desired results. Du Plessis’ argument in this case is that they have not, but concludes that 'feminism', 'the state' and 'women' are such complex concepts that they are likely to generate diverse and fragmentary strategies. Although Du Plessis’ case studies are not directly linked to this research, they offer an important insight into feminist policy in New Zealand. All women - secular and evangelical - have a vested interest in policy regarding employment equity. This relates back to the research specifically because the majority of women interviewed for this research are employed outside of the home in the secular workplace. An exploration into secular legislative as well as personal histories from New Zealand feminist scholars identifies that there is a lack of analysis of religion as a variable. Feminist literature in New Zealand is significantly dominated by secular ideology, which allows for religion to be overlooked and under-represented. The gap in New Zealand literature paves the way for this research to contribute to the study of religion within feminist studies in New Zealand generally.

\footnotetext{
${ }^{93}$ Rosemary Du Plessis, "Stating the Contradictions: The Case of Women's Employment" in Rosemary Du Plessis and Lynne Alice (eds.), Feminist Thought in Aotearoa /New Zealand: Differences and Connections (Auckland, N.Z.: Oxford University Press, 1998), 215.

${ }^{94}$ Ibid., 209.
} 
Feminism in New Zealand has been defined as a substitute for state religion - a state ideology that is not officially acknowledged. ${ }^{95}$ It is entrenched in New Zealand history, education and media and is home to prominent feminist scholars. Feminism has a reputation for being scathing of religion which prompts the question, "Do you have to be secular to be a feminist?” This research challenges this notion, outlining evangelical women's feminist perspectives which have developed through their involvement with secular society. Religion has become a recurring topic in feminist writings and for the right reasons. Religious women are finding their voices and are contributing to public life. The feminist movement and evangelicalism that were once perceived to be poles apart are now forging a new evangelical feminist identity which has surged into evangelical scholarship. Whether New Zealand evangelicals identify with feminist values is a significant part of this research. The level of influence of second wave feminism as outlined by Bunkle, Waring and Du Plessis will be a significant factor in determining how feminist evangelical women are.

\section{Conclusion}

The exploration into feminism as part of the identity of evangelical women is a critical study. How women manage this apparent conflict while at the same time living as liberated women in a secular society is important to the future research on evangelical women in New Zealand. Whether evangelical women identify with feminism as a symbol for liberal society is fundamental to the way in which women interact with religion in today's society.

\footnotetext{
${ }^{95}$ Peter Zohrab, “State Religion is Feminism,” The Dominion Post, May 22, 2006, Features.
} 
As evangelicalism continues to expand globally, the study of how women manage their faith in secular liberal society is becoming more relevant and important in today's context - and especially in New Zealand. It is important to understand how feminism, as a symbol of secular liberalism, is significant and to ascertain how evangelical women negotiate the often-conflicting demands and rewards of their membership in their religious community and the larger society. The theme of 'obligation versus liberation' illuminates and attempts to make sense of the conflicts evangelical women face. From time immemorial women have answered to men in family, politics and business, with limited rights in the church and even limited participation in public life. It is not only in Christianity that equal rights for women are a great unfulfilled concern - there is apprehension among sacred and secular communities globally.

This research focuses on the perception evangelical women have of feminism. It asks, 'How do evangelical women use feminism as a way of coping with conflicting demands in New Zealand secular society?' Are evangelical women so committed and obligated to God that they forget or do not notice that they are also women of liberation? For centuries women aimed to achieve equal status with men, and this is reflected in the feminist movement worldwide. What is it that motivates the modern-day woman to be attracted to a faith that essentially reverts back to traditional gender roles? ${ }^{96}$ Is this not a step backwards in terms of women's liberties? What is fascinating is that the feminist movement and the rise of evangelicalism in New Zealand occurred virtually simultaneously, suggesting they can be seen as parallel social forms. Many pioneering women, supporting both evangelical and feminist causes separately, joined forces on

\footnotetext{
${ }^{96}$ For an alternative argument on the rise of evangelicalism and the demise of liberalism, see Ron Johnson, "The Good News about Evangelicalism: Evangelicalism Isn’t Shrinking and the Young are not Becoming Liberals,” First Things: A Monthly Journal of Religion and Public Life 210 (2011): 12.
} 
social matters such as the temperance movement and the banning of pornography. ${ }^{97}$ However, for most people the terms evangelical and feminism are contradictory. How can an evangelical, who supports social conservatism and traditional gender roles, also support feminism, a movement that seeks to redress the inequalities, injustice and discrimination that women face because of their sex? Surely a person cannot hold true to a feminist ideology and a conservative theology at the same time? There is, however, significant literature related to evangelical feminism - a belief that, when interpreted correctly, the Bible teaches the equality of women and men. It is possible that evangelical women have adopted feminist values while maintaining a conservative theology, as a way of negotiating the conflicting demands placed on them by secular liberal society.

This qualitative case study provides a snapshot of who evangelical women are -their religious upbringing, education, employment and conversion experience. Interviews and observations were used to collect data in the areas of personal information, conversion to evangelicalism, life as an evangelical Christian, the role of women in New Zealand society, women's role in the church, roles of men and women in the home, social issues and secular society. The primary goal was to reveal the relationship between evangelical women and their identification with feminism and how this contributes to their understanding of the world.

${ }^{97}$ Elaine Storkey, What's Right with Feminism? (London: SPCK, 1985). 


\title{
CHAPTER THREE
}

\section{METHODS}

\begin{abstract}
Although there is a strong relationship between evangelical Christianity and anti-feminism, this should not obscure the fact that there is among evangelical women a fair degree of support for feminist positions. ${ }^{98}$
\end{abstract}

Research on evangelical women in New Zealand is an example of the changing nature of religion. In New Zealand society, adherence to, and identification with, religion is steadily decreasing according to Census figures. However, simultaneously, alternative strands of Christianity such as evangelicalism and pentecostalism are increasing in membership and experiencing growth across organisations. This makes evangelical churches an important case for the study of how women negotiate feminist values while being adherents of traditional religion. The study of evangelical women reflects changes in society, community and individual norms through the patterns of adaptation for survival in an evangelical subculture. This research opens up New Zealand evangelicalism to the global evangelical community. In a literature heavily overrepresented by case studies from the United States, it is now possible for comparisons to be made with other countries such as New Zealand. There are vast amounts of literature addressing evangelicalism, religious history, feminism and women. What fails to be adequately addressed, however, is evangelical women's response to liberal society, symbolised by evangelical feminism. How women who remain part of traditional religious institutions and embrace a feminist identity negotiate these identities,

98 Clyde Wilcox, "Feminism and Anti-Feminism among Evangelical Women," Political Research Quarterly 42 (1989): 147. 
especially in New Zealand society and culture, needs to be examined. This research assesses how reconciliation of identities, for women who accept feminist values and are committed evangelical Christians, is possible. It particularly fills a gap in scholarship on evangelical churches in New Zealand.

This research will examine whether evangelical women in New Zealand are feminists. As New Zealand is a country significantly influenced by the feminist movement, this research will indicate to what extent the feminist movement and its values have influenced evangelical women. Gender roles are pivotal in identifying the dynamic of women and their autonomy in family, church and societal life. The impact of gender roles on the daily lives of evangelical women, and whether this is significant, is a crucial factor for this research. Through this study, the conflict between women living in a secular society while being women of faith will be uncovered. These roles foster conflict which leads to the question: "Do evangelical women struggle to negotiate the different roles in their lives?”

The experience of women in evangelical churches in New Zealand will be researched through interviews to determine if there is a contradiction between secular and religious life. This research will discover whether evangelical women are feminists by delving into issues such as gender roles in the church, home and workplace. Women's role in secular society will be discussed, with factors such as employment and friendships being examined, to assess the levels of autonomy women have in this setting compared with their role in the family and in their church. It is important to evaluate the negotiations women have to make between secular and religious life. The research will discuss the challenges women face from secular society and non-Christians as well as their questions regarding their faith. 


\section{Setting}

This study took place in three evangelical churches in New Zealand - two located in Wellington and one in Hamilton as case studies of the broader developments of evangelical women in New Zealand. Lighthouse Christian Fellowship in Hamilton was born out of a desire of the current pastors to reach out to the non-English speaking Asian community living in New Zealand. Established in 1993, Lighthouse Christian Fellowship joined the New Life International stream in 2006, a parent body of many different churches where each church is autonomous. The congregation is heavily Asian, with members from places such as India, Korea, Singapore, Malaysia and China. In Wellington, The Rock was established over 20 years ago by Anthony Walton and is based in a converted warehouse in the industrial area of Ngauranga Gorge. It has a strong community focus as a mission-centred church. Two of The Rock's ongoing community projects include the House of Grace, a non-profit organisation providing a home for young pregnant women who have limited resources and often no home to go to. The Rock also established Zeal, a non-profit community organisation that was conceived in 1998 as a facility for youth events and activities. The Rock Church, through Body and Soul Trust, in partnership with the Wellington City Council, conceptualised Zeal to provide a central and safe social environment for Wellington's youth. Both organisations serve Christians and non-Christians. Encompassing a similar focus on mission is Lifepoint Church, an Assemblies of God Pentecostal Church in Wellington. The oldest of the three churches, Lifepoint has a membership generally characterised by longevity in the church. Many of the Lifepoint members interviewed had attended the church for more than 10 years. Lifepoint has a significant message regarding social justice through programmes such as World Outreach, which supports 
and resources mission individuals who are involved in developing local leaders, evangelism and church planting. World Outreach focuses its activities on the leastreached people groups, mobilising people in mission, children's ministry and humanitarian relief work.

With the churches being based within cities access by participants is easy. Of the participants interviewed, all were women between the ages of 18 and 70 . The majority of respondents were New Zealand European at 74 percent, 21 percent were of Asian descent and 5 percent were of Māori-European heritage. As there were limitations when finding participants for this study, Māori women are underrepresented in this research. This is due to the churches that were studied having a small percentage of the church that was of Māori ethnicity. The researcher initially made contact with the senior pastors of the churches to request permission to research their churches and to find participants within them. The pastors then sent emails to women from the congregation who they thought would be interested in the research and participation in the study. They also discussed the study with women at Sunday services as well as women's groups and passed on the researcher's contact information to those who were interested. Women from the churches gradually communicated their interest and meeting times were set. The participants were asked to fill out a demographic survey as well as sign a consent form prior to the interview being conducted. The interviews were mostly conducted in the women's homes. The other interviews were conducted at church, in a park and in a café. The length of the interviews was varied - some were 30 minutes and others were two hours. 


\section{Sample and Participants}

The sampling procedure used by the researcher was purposive sampling. Purposive sampling starts with a purpose in mind and the sample is thus selected to include people of interest and to exclude those who do not suit the purpose. Therefore, evangelical churches were chosen and the target subjects were women in a conservative religious institution. Males and secular individuals were excluded purposefully from this research. The churches were chosen on the basis of their profile in the religious community and the researcher's familiarity with an attendee. The process of finding participants was restricted to The Rock and Lifepoint in Wellington and Lighthouse Christian Fellowship in Hamilton, New Zealand. The churches were also chosen for their accessibility to the researcher.

Familiarity within the church community was established and was accomplished by regular attendance at services to allow women to show interest and voluntarily make contact if they wanted to participate in the study. At the beginning, responses were few and it was difficult to reach the number of participants needed for the study to be substantial. Subsequently the participants volunteered and every participant was required for the study. It was fortunate that the women interviewed provided a range of different age groups, ethnicities, socio-economic statuses, employment statuses and religious upbringings. Participants in this study included 20 women - six from The Rock, eight from Lifepoint, five from Lighthouse Christian Fellowship, and one independent evangelical Christian woman who was an acquaintance of the researcher. The participants were asked to take part in a demographic survey before the researcher conducted face-to-face interviews. 
The participants in the study represented a diverse range of demographics. The average age for a participant was 44 years, with the 25 to 40 age bracket slightly dominating with 37 percent. Twenty-one percent of the women were between the ages of 18 and 24, 32 percent between 41 and 54, and women between the ages of 55 and 70 comprised 11 percent. Of the 20 women interviewed, work outside of the home dominated, with 73 percent of participants engaged in paid employment. Sixteen percent were in the home full time and 11 percent were students. The majority of women interviewed (53 percent) were married; however, single women still made up a significant proportion at 37 percent of participants. Five percent of participants were divorced; the same number were engaged. A small gap divided those who had children at 42 percent and those who did not at 58 percent. There was a significant majority of women who had attained higher education. Seventy-four percent of participants had either a bachelor or postgraduate degree. The average household income was reasonably high at $\$ 80,000$ per annum. There was a wide range of religious upbringing - nine distinct religious affiliations for the 20 women interviewed. This is significant because the women bring various religious histories to this research. Pentecostal/evangelical was the most dominant religious upbringing at 20 percent. Second equal were Anglican and Roman Catholic denominations each with 16 percent. Presbyterian, Baptist and Assemblies of God denominations were third with 11 percent each. Similarly, no religion, Buddhist, and Methodist were equal, each with 5 percent. The demographic survey asked when the participants became evangelical Christians - 37 percent stated as a child, 32 percent as a teenager, 26 percent as an adult and 5 percent through marriage. Participants had been at their current church for an average of 10 years. 


\section{Measures}

The interview questions were aimed at providing a snapshot into the lives of the evangelical women interviewed. Broad questions such as "tell me about yourself", partnered with specific questions such as "tell me about your religious upbringing" highlight the different focus of questions asked of participants. Section One of the interviews started with a broad outline of the respondents' lives - who they were, what their upbringing was like and what their life is like today. These generalities provided an insight into the women's life experiences and set the context and understanding for further, more specific, ideas to develop. The interviews were intended to provide the information needed for the researcher to interpret the relationship between evangelical women and their identification with feminism and how this contributes to their understanding of the world. It was important for the researcher to know not only what it was that motivated the participants to choose the evangelical path but also how the women experienced life as evangelical Christians. This would contribute to the research outcomes as it showed the basic premises of their beliefs.

Participants were asked if they identified with feminism, which was the crux of what this research sought to determine. This question gave the respondents scope to outline their feminist views, or lack of them, with questions regarding women in secular society. This question allowed them to think about feminism, and how it has impacted their lives, and then to draw out their beliefs about women in traditionally male dominated careers and women's discrimination in the workplace. This provided the researcher with invaluable information and the opportunity to build the research in a way that answers the research questions. Furthermore, the issue of women's role in the church was discussed. It was interesting to see whether the participants' views of 
women in secular society reflected their views of women's role in the church. Similarly, the respondents were asked to identify the 'proper' roles for women and men in the home. This followed on from questions about feminism, women and secular society, and women in the church, to ascertain whether their views were contradictory or had changed throughout the discussion of women in all spheres of life. It was interesting to see the parallel views between sacred and secular life. For example, a significant majority of women worked outside the home in secular employment; however, they held the same views across church boundaries as well. Studies show that evangelical women are more conservative on social issues, such as abortion and homosexuality, than their secular counterparts. ${ }^{99}$ The evangelical standpoint on these issues was researched and insightful conclusions were found which provide evidence for the argument that evangelical women are accepting a more feminist stance.

Less central than the face-to-face interviews, but still providing an important insight into women's lives in church, was the observation technique. The researcher spent significant time in church services and with participants after the service had finished to observe communicative behaviours. This time allowed for observation to be used to collect data on women in their own religious space, experiencing God in their own personal way. The observation, not only of the interviewed women but the congregation in general, provided noteworthy information on the manner in which women interact in a service. The main observation technique was to sit in a two-hour service on a Sunday and to write notes based on what the researcher witnessed in the congregation. Women were active in the services across the three different churches - they spoke, they sang and they participated. The purpose of the observation was to understand the women in

${ }^{99}$ Clyde Wilcox, "Feminism and Anti-Feminism among Evangelical Women," Political Research Quarterly 42 (1989): 147; Clyde Wilcox, "Evangelicals and the Moral Majority," Journal for the Scientific Study of Religion 28:4 (1989): 400-414. 
their own church context - how they perceive their lives and role in the church situation. This was significant for the researcher, as it provided firsthand experience of women who were not in a formal interview situation - they were actively and comfortably participating in the church environment. An example of the behaviours observed were: smiling, laughing, physical contact, shouting, close range proximity to the congregation and pastor, long range proximity to the congregation and pastor, positive comments and singing. The communicative behaviours were tallied to produce a frequency account of each type of behaviour. In addition, descriptive and reflective comments with regard to the communicative behaviours were noted.

\section{Data Collection and Procedures}

The main method of data collection was structured interviews with 20 participants - six women from The Rock, eight women from Lifepoint, five women from Lighthouse Christian Fellowship and one independent evangelical Christian woman who was an acquaintance of the researcher. This small sample was selected to provide quality and in-depth information and to enable efficient analysis. The interviews were structured with a schedule of prepared questions to provide a more uniform collection of the information and assured the comparability of the data. Interviews were chosen not only because there is little data in New Zealand on evangelical women, but also because in complex situations it is appropriate that the researcher had the opportunity to explain the questions to the respondent in person. This minimised the likelihood of a respondent misunderstanding a question, which aids in the validity of the research. Interviews also allow for demographic profiling, which provided a basic understanding of who the 
women are - for example, their levels of education, socio-economic status, ethnicity and age. This was to provide comparators to enable the study of the differences and similarities between the women in the churches. Challenges arose because the interviews were time-consuming. Furthermore, the quality of the data is dependent on the quality of the interaction between the respondent and the researcher as well as the quality of the researcher's interviewing skills. These challenges were overcome by allowing a certain time frame for each interview and improving interview skills to achieve the best possible interviewing situation. A detailed schedule structured the interviews. The respondents were asked the same questions unless a specific question did not apply to that individual. This meant that the interviews consistently measured the same objectives and thus allowed for more reliability in the research.

The data was collected through interviews and observations. The observations were collected under natural, non-manipulative settings in the participants' churches. The researcher was a non-participant observer and sat at the back of the room to avoid any interference to the setting. The data collection process took place over a seven-month period for all observation and interviews. This was a significantly long period of data collection - there were complications with contacting churches and having to change the churches being researched. Because it was vital to have the full cooperation of the churches' pastors before research could commence, establishing an adequate level of trust similarly consumed time. As well as church limitations, finding a time to suit each individual participant for a one-hour interview was extremely time-consuming and led to a long period of data collection. Observations took place once every two weeks at the church services for a two-hour period, totalling 14 observations. While some interviews were conducted individually at different sites including at participants' churches, the 
majority were in the women's homes. All interviews were digitally recorded for accuracy with the exception of one participant who preferred not to be recorded; therefore, in that instance detailed notes were taken.

\section{Data Analysis}

The data analysis was systematic and organised. Procedures were recorded in detail so that short descriptions of them can be detailed in the research. Data was coded and analysed, giving meaning and purpose to the data gathered. It contributed to the understanding of meaning and purpose in the behaviour of others. Shared features and variation, both within and across interviews are identified. The collected data was transcribed and categorised in terms of research questions and emergent themes.

The methodology used to analyse the meaning of the recorded interviews is content analysis. Ole Holsti offers a broad definition of content analysis as "any technique for making inferences by objectively and systematically identifying specified characteristics of messages”. ${ }^{100}$ The method of content analysis enables the researcher to include large amounts of interview information and systematically identify its properties. Examples include the frequencies of most-used keywords such as identity, feminism, secular and submission by locating the important structures of its communication content. The end result provides a significant and critical reading of the interview content identifying concepts, themes and trends.

\footnotetext{
${ }^{100}$ Ole R. Holsti, Content Analysis for the Social Sciences and the Humanities (Reading, MA: AddisonWesley Pub. Co., 1969).
} 
The interviews were intended to provide information for the researcher to interpret the relationship between evangelical women and their identification with feminism, and how this contributes to their understanding of the world. It was important for the researcher to know what motivated the participants to take the evangelical path and how women experienced life as evangelical Christians. This would contribute to the research outcomes as it showed the basic premises of their beliefs. This qualitative case study provides a snapshot of the contemporary evangelical woman. It details their religious upbringing, education, employment, and conversion experience. The data collates information regarding conversion to evangelicalism, life as an evangelical Christian, the role of women in New Zealand society, women's role in the church, roles of men and women in the home, social issues and secular society. These seven areas are the main themes within this research and the narrative data was transcribed, coded and categorised into these seven themes. The primary goal was to reveal the relationship between evangelical women and their identification with feminism and how this contributes to their understanding of the world. Specific interview questions were matched to answer the research questions. A coding method was used to organise interview data into a limited number of themes and issues around these questions. Quotations were then selected from the interviews that illuminated the themes and concepts. Specific survey questions and demographic data were matched to the specific research study questions. Data from the demographic survey was also compared with data from the interview to examine if they were in collaboration. 


\section{CHAPTER FOUR}

\section{RESULTS}

\section{Women's Profiles}

Laura attends an evangelical church, but is firmly embedded in her Catholic roots. She has undergone extensive university study and now works in education management. She is married with four children. Laura is adamant about her views on feminism. She states she would be disappointed and would want to offer counselling to any woman who did not call herself a feminist, as well as most men. She believes that Jesus was a feminist and if you are following him it is hard to justify following another position.

Nancy came to New Zealand eight years ago and is Malaysian of Chinese descent. Her husband is an atheist and her children have been brought up as evangelical Christians. This has caused tensions at stages throughout their family life. Nancy converted from Buddhism to Christianity at a young age, as did her brother, which caused significant problems within the family. Nancy is currently employed by her church.

Ruth has had a problematic journey of faith when she felt that all that she had believed unravelled. This is when she became an evangelical Christian and said God met her in a very personal way. At 38 Ruth is married, has two children and is a full-time mother. Although she says she hopes she is not a feminist, Ruth continues to identify with feminist values in her discussions of male headship and women's involvement in church services.

Donna defies assumptions - she is a 24-year-old Malaysian engineer of Chinese descent. Based in a male dominated workplace, Donna experiences many challenges 
with her faith and struggles with her almost exclusively male workplace on a day-to-day basis. She chose an area of engineering to specialise in purely because it was more female-friendly. Donna grew up in a non-Christian home and became a Christian as a teenager. She strongly identifies with feminism and this is also evident in discussions of her engineering career.

Isabella is a 22-year-old woman finishing her law degree at Victoria University of Wellington. At the time of interviewing she had recently become engaged to a man who is a fellow member of her church. Isabella was raised in a Baptist family and has been a Christian from a young age. She identifies herself as a feminist and is involved in working with community groups such as Women's Refuge and a community justice project which she co-founded.

Patricia is a single 34-year-old woman who works as an administrator. She was not raised in a church and became an evangelical Christian as a teenager. She identifies herself as an evangelical Christian and as a feminist. Patricia places significance on women in leadership and opportunities in the church. She believes that feminism changed the world and affected all societies and organisations - church included.

Linda grew up in a Presbyterian home but did not see herself as a Christian. Linda is an independent woman in corporate employment and is in a high socio-economic income bracket. She found her evangelical roots as an adult. At 43 , she is divorced and has no children. For Linda the Holy Spirit aspect of church is essential. She formally identifies as an evangelical Christian and does not see herself as a feminist. However she places significance on what the feminist movement has achieved for women today. 
Barbara was brought up in a strict Catholic home. She faced many challenges growing up with her father, who was an alcoholic and was violent. She subsequently turned to a life of "living in sin” with drug and alcohol abuse. Barbara became an evangelical Christian as an adult and is now a successful marketing and communications administrator who is married with two children. She has an exuberant outlook on life the spiritual aspect for Barbara has been significant for her because of the hardship she has experienced.

Elizabeth comes from a non-Christian family and became an evangelical Christian as a teenager through friends. She is single and at the age of 32 values being 'real' and being able to communicate the relationship she has with God quite openly. Coming from a non-Christian family has presented challenges as there were many assumptions that came with her religious transition from her family. Elizabeth identifies as a feminist and supports women having opportunities for God-led leadership in the church.

Jennifer is the youngest woman interviewed. At 18, Jennifer is significantly involved in church activities such as youth interning as well as studying at Bible College. She experienced a significant drift away from God and reconnected at the age of 15 . Working in a secular environment, Jennifer has found immense pressure from peers and colleagues regarding her Christianity. She does not identify specifically as a feminist but does indirectly encompass feminist values.

Maria is a 32-year-old primary school teacher with a postgraduate degree. Her parents were significantly involved in a pentecostal church, so her religious upbringing has influenced her direction to evangelical Christianity. Maria is involved with the church’s children's ministry and spends three days a week on church activities. She does not like 
the feminist label, but indirectly identifies with feminist values such as the importance of women in church leadership.

Susan is a young successful career woman. At 29 she is married and has studied and travelled extensively. Susan was brought up in an Assemblies of God church, so having a spiritual life and faith was very much part of her Christian upbringing. She has experienced tensions in her faith and to combat this she focused on social justice projects, which were significant in her faith experience. Susan is a strong believer in male and female equality, while at the same time she believes in a strong gender difference. Susan's goals are to develop a more extensive and meditative life.

Margaret was brought up in a Catholic home and has had significant tensions with her Christianity which have taken a long time to reconcile. She became an evangelical Christian in adulthood and is now a successful researcher at the age of 43. Margaret identifies with feminism. She is single and has a postgraduate degree.

Dorothy is interesting in that she lives in an intentional Christian community. She made the decision to live in the community in order to live with other Christians in a way that is environmentally and socially sustainable. At the age of 22, Dorothy is single and is a policy advisor with a postgraduate degree. She was brought up in a Baptist church environment where social justice was significant, which has heavily shaped her decisions and actions. Dorothy has only recently been back at church after a six year break.

Lisa is a single 45-year-old woman who has had a fascinating religious history. Her parents were missionaries and belonged to a Peruvian evangelical church. Her spiritual journey has been one of having to cope with what it means to grow up in a missionary 
family. It has had a significant impact on her life and faith. Lisa identifies as a feminist and feels strongly that women should have leadership roles in the church.

Karen is a co-pastor with her husband. She was raised in a moderate Anglican family but did not identify as a Christian. She and her husband were both negative about religion until a family member's persistence provided an opportunity for them to experience evangelical Christianity. At 57, she spends most of her time in her pastoral role and looking after the children's ministry. Change and freedom have come from her spirituality.

Helen is a full-time mother and is Malaysian of Chinese descent. She moved to New Zealand as she and her husband believed that they concentrated too much on their work and not enough on family life. As Helen was from a free-thinking family in Malaysia, her conversion to Christianity was uncontroversial. Helen has a conservative view on women's role in the church and in the family, seeing the benefits of women's submission and disagreeing with women in leadership in church at the pastoral level.

Sandra studied law, economics and accounting and had a corporate career before giving up work at 26 to be a full time mother. She is from Malaysia of Chinese descent and comes from a free-thinking family. While Sandra states that she is not a feminist, she has evident feminist values. Finding herself to be quite bossy and independent in her own right, she has had issues around submission to her husband. This is an ongoing learning experience for Sandra.

Sharon is a long-standing member of her church having attended it for nearly 30 years. At 61 she is now a teacher aide; however, she has had an interesting career history in information technology at a time when the IT industry was exclusively male. Sharon 
was raised in an Anglican family that taught equality and she feels she has never experienced discrimination in the workplace - quite the opposite. For these reasons Sharon does not identify directly as a feminist.

Michelle has had a tumultuous life, moving from the United States to New Zealand and being estranged from her family. At 65 she has had a career in psychological therapy and has had a significant involvement in evangelical training programmes that have spanned New Zealand and Australia. Michelle is divorced with no children and has been a member of her church in New Zealand for nearly 20 years.

A salient characteristic of evangelical women is that they are typical, yet they challenge the norm simultaneously. There are qualities in being evangelical women that their secular counterparts do not experience. Evangelical women manifest a unique sense of fulfilment in their lives that is different from the experiences of secular women. The participants discuss a 'love' that they receive from God that supports them in ways that secular women cannot comprehend. Evangelical women similarly have a more difficult time justifying their views or acts that aren’t perceived as traditionally Christian. There is immense pressure on evangelical women to be the 'good' Christian as outlined in scripture, as well as have a life outside of the church in a secular society. Whereas evangelical women have to negotiate these challenges, secular women do not have to take into consideration traditional gender roles regarding the family, church life and employment.

The women interviewed for this research varied in many demographics such as age, occupation, ethnicity, socio-economic status and education levels. With differing demographics came varying opinions concerning the main themes of this research: 
living in two worlds, women's role in church and society, and evangelical women's life fulfilment. As well as differences, there were also recurring opinions and themes discussed by the participants, such as challenges, feminist identity and women's ideals. This research has revealed a gap between rhetoric and reality as women negotiate the challenges of living in two worlds. These themes are highlighted below and will be further discussed in chapter five.

\section{Living in Two Worlds - Evangelical Women’s Experience}

The Difficulties of Being an Evangelical Christian

Like their secular counterparts, evangelical women experience difficulties and challenges, but as women of faith. Some women are stuck at a crossroads between secular and religious life while others cannot express themselves to the fullest extent because of fear of alienation. As Isabella explains there are many assumptions that come with being an evangelical woman and it is easy for others to stereotype:

The most difficult thing is when other people put you into a box before they even know you, or at the same time when I put myself into a box or put God into a box and feel like there is one set of rules to live by. It is really easy to buy into that mentality, but it is wrong. And so that is challenging - to live a life of freedom but at the same time to be involved in church - the temptation is to live by lots of rules and heaps of tiny little regulations and they end up restricting your freedom and your ability to be with God's spirit.

Isabella's discussion of the challenge between living as a free woman and being a woman of faith highlights the contradiction of a young woman trying to live in a secular world and religious one. Where women such as Barbara and Linda highlight the 
challenges of being in the world but not of it, meaning that the most challenging things are "not doing the things that are worldly, accepted and that happen all the time". Isabella is attempting the opposite- to be in the world and of it, while negotiating the difficulties that come with being a young Christian feminist woman living from day to day in secular society.

Isabella's perspective is significant - she states that her faith is extremely strong and that she does not question it, and at the same time she draws on a conflict she evidently has with her religious beliefs by outlining the lack of freedom she feels while being involved in the church. The pressure of the post-modern has influence and the way Isabella discusses her issues reflects that. Isabella has an ongoing fusion with the secular world: she has secular friends, a secular education and is involved with secular organisations. Isabella is therefore seeing ideas and expressions that she does not and cannot have. This causes tension between her faith and her commitment to the church, on the one hand, and the secular environment she finds herself willingly participating in on the other. Isabella describes her faith in a very idealistic manner. She does not detail her struggles of faith in depth; indeed she barely scratches the surface. Her answers to interview questions seem very stereotypical and incomplete; however, this may be because she was aware she was talking to a non-Christian researcher and wanted the researcher to hear the ideals of life as an evangelical Christian. Because faith is a personal experience, other women interviewed expressed a less idealistic Christianity.

Evangelical women find it a challenge to maintain their religious personas in all facets of life. Elizabeth noted that a personal challenge for her was consistency. She wanted to be the person that she was on Sunday in all facets of her life. It was imperative that everyone saw the same thing. "We are all very good at putting masks on but I want it to 
be consistent over my entire life not just on a Sunday or when I am hanging around with my Christian friends.” The challenge for evangelical women to be the same person in two different worlds extends to family life as well. Nancy is an interesting case study as she is the only participant whose husband identifies as an atheist. Her daily life involves living in two worlds as she accepts the challenges of living with her husband's nonChristian worldview.

My husband has no faith, no belief. He is an atheist, he doesn't believe in anything. Before we had [the children] there was no problem. I went to church on my own, but when [the children] were growing up I took them with me to Sunday school and they have been growing up with me so they don't know anything about any other religion. I do find it harder now because they go to youth group and when [we] are at home [we] don't pray, [we] don't say grace because my husband is around. We tried it but then I said to the kids, 'just do it on your own'.

Nancy's husband's atheism highlights a conflict she has that a secular woman would not face with a similar spouse. This example shows the different factors evangelical women need to take into account - such as how personal decisions influence faith. Nancy made a decision to marry a non-religious man and this has consequently shaped the way she, and now her children, practise their faith on a daily basis. The only significant difficulties Nancy has with being an evangelical woman is in her family life. She talks about her evangelical experience from the perspective of a woman who is employed by her church, has almost exclusively Christian friends and has not been in New Zealand for a considerable period of time. Her bias is in favour of her church as the only conflict she describes is in the family. Had Nancy experienced some secular culture in New Zealand then this may have eased the tension between her faith and her husband's atheism. 


\section{Challenges from Non-Christians in Secular Society}

Participants in this research detail the challenges they have faced from non-Christians. This has led to difficulties when trying to be open about their faith with the result that some have ceased expressing their religion at all within secular society. Thus these women are finding it extremely difficult to be the same person on a Sunday as they are in their secular settings mainly because of prejudice and the fear of rejection.

Dorothy has found challenges with university life as a young evangelical woman. She faces significant difficulties regularly with her university friends. They are all studying postgraduate education in political science and international relations and call themselves atheists. Dorothy feels that she has to continuously justify herself and her faith particularly because she lives in an intentional Christian community. She has friends who are involved in pro-abortion rallies and although she does not wish to attend them, she certainly does not get asked to participate. “The thing is they didn't ask my opinion they just assumed it. I can understand why they have - I just think most people’s views of the church and Christianity are not positive and I think the church has a lot to answer for.” Dorothy's reasoning is clear - it is the fault of the church that society has a negative view of it. She is a very uncharacteristic evangelical woman. In one part of her life she is living as an evangelical in an extremely secular environment, such as her secular workplace, but the fact that she lives in an intentional Christian community confirms her Christian identity. Clearly Dorothy wants to have the best of both secular and religious worlds but where is the line drawn? Dorothy is extending out both secularly and religiously and this can cause significant conflict between the two worlds she is living in. Her statements are not entirely logical - she changes from secular mode to Christian mode almost instantly, which is rather confusing. This shows how 
evangelicalism is changing and adapting to secular culture so that women such as Dorothy can be evangelicals while subscribing to secular values as well. It is almost a forced reinvention in this case. At 22, Dorothy is an example of the post-modern woman who embraces evangelicalism on her terms and challenges the norm.

Most women recognise that issues such as abortion and homosexuality are sensitive and personal subjects for most individuals. Patricia considered her views on working with secular colleagues and how this can be difficult when conscience issues are brought up for discussion. She found that a lot depends on how you present what you think. When issues such as abortion or homosexuality are brought up at work all eyes turn to her for the Christian perspective on the topics and she thinks that this is very difficult. Maria agreed, stating, “it was so easy when you are at church and you are surrounded by Christians but when you think about sharing with your colleagues you hesitate because they will not understand." Susan also felt she could not express her faith in her workplace. Her colleague injured his knee and Maria told the researcher, "I am praying for him and it is getting better but I am not telling him that because he will think I am weird.” Evangelical women are more reluctant to broadcast their beliefs about issues such as prayer, homosexuality and abortion because of mounting pressure from secular society. Society in New Zealand is changing and with that evolution evangelical women experience a less tolerant secular society. Current society judges religion more harshly than in the past and this has led evangelicals to adapt and change in order to maintain and even grow their religious movements. Evangelicalism wants to remain relevant and it will only achieve this if it moves with secular culture, not against it. 


\section{Women's Role in Church and Society}

Radical Feminism

Radical feminists are labelled as slogan-makers and man-haters. ${ }^{101}$ However, radical feminism is easier to stereotype than it is to define. Radical feminism identifies and opposes male domination and prioritises sexual rights. ${ }^{102}$ It similarly fosters a womancentred culture that turns its back on patriarchy. ${ }^{103}$ In this research radical feminism has been used to categorise women who expressed an atypical amount of support for both feminism and feminist principles. It does not necessarily mean that these women support all of these philosophies - radical feminism is an idealised category adopted to distinguish these women from their more moderate counterparts. Generally, the women interviewed who express views applicable to the radical feminist category had attained a higher level of education - most at tertiary level with a bachelor or postgraduate degree. This level of education and exposure to the influence of secular institutions could explain why these evangelical women encompass a more obvious feminist identity.

Laura is passionate about her views of feminism because she believes women are marginalised in the church. She speaks freely about her feminism and the issues she has experienced through her faith. When asked if she sees herself as a feminist she replied, "Hell yeah! Yes, of course. I would be disappointed and would want to offer counselling to any woman who didn’t call herself a feminist, and most men. Because I think that Jesus was a feminist and following him - it is hard to justify following another position. I hope that came across nice and strong.” Laura is extremely intelligent, highly educated and articulate, and while discussing her views on feminism

\footnotetext{
${ }^{101}$ Elaine Storkey, What's Right with Feminism? (London: SPCK, 1985), 90.

102 Denise Thompson, Radical Feminism Today (London: SAGE Publications Ltd., 2001), 3.

103 Elaine Storkey, What's Right with Feminism? (London: SPCK, 1985), 104.
} 
she very much assumed a logical and scholarly mode. Her perception of feminism clearly comes from her experience and education through secular institutions; therefore Laura has been influenced by secular society and has been exposed to a different style of feminism. More conservative evangelicals would disagree with Laura's views as they are uncharacteristic regarding traditional gender roles. Laura's argument demonstrates the 'radical' end of the evangelical feminism spectrum. Of the women interviewed there are generally more evangelical women in support of feminism than not; however, the participants’ levels of support are still varied.

Michelle is in a leadership position in her church and has been for some time. She believes that some people disagree with the church having women elders. Michelle has no problem with male authority but she strongly thinks that every individual is entitled to work within their gifts. "I have always admired that [my church] will have women elders, which I know a lot of churches think are biblically wrong. I know some men in our church who think that it is biblically wrong, but when 70 percent of the church is female you need some leadership to help women.” Michelle’s view is significant - many evangelicals quote 1 Timothy 2:12 as a justification for women to stay out of church leadership; however, it is accepted that women teach women and children. Therefore it is important to have women in leadership when such a large part of the congregation is female. This view creates tension in the church community as women identify their congregation as mainly female, but lacking in female leadership.

\section{Liberal Feminism}

Whereas radical feminism concentrated on sexual rights, liberal feminism has traditionally been concerned with political rights. Liberal feminists have pursued non- 
sexist educational programmes and new legislation that will ultimately result in the freedom of women. ${ }^{104}$ Liberal feminism encompasses optimism that is unique to its ideology. The compatibility of feminism and evangelicalism is a central theme of this research; therefore it was necessary to investigate evangelical women and feminist identity. The liberal feminist category was significantly dominated by the 25 to 40 age demographic, with nearly half of participants represented in this age group. This is likely to be due to the influence of second wave feminism, which addressed a wide range of issues such as sexuality, pornography, family, the workplace and, perhaps most controversially, reproductive rights in the 1960's and 1970's. Women in this demographic were mostly influenced by the women's movement and either identify with the movement directly or have memories of the movement indirectly.

Though there were differing opinions, every woman interviewed encompassed some form of feminist value, whether it be supporting pay equity or equal decision making in the home. Susan felt strongly about both issues, highlighting that she fervently believes in equity and thinks that men should contribute around the house. "If my husband and I both work 40 hours a week then we both need to do an equal share of the housework and childcare. I don't like there being strong male or female associations particularly in manual labour; I am pro pay equity.” Susan has no problem being labelled a feminist, as was evident with many of the women interviewed. Susan supports the political side of feminism as she is mainly influenced through her daily involvement in a secular environment. Being in a younger age demographic, Susan holds strongly that it is a necessity for both men and women to be in full-time employment and share domestic labour. Susan is a good example of an evangelical women living in two worlds -

${ }^{104}$ Elaine Storkey, What’s Right with Feminism? (London: SPCK, 1985), 59. 
everything is secular in Susan's life apart from church on a Sunday. Her emphasis on women's role in the home, church and society reflects the post-modern woman we are seeing in society today.

Some of the women felt they were feminists once, but do not currently identify as such. Donna is similar to Susan as, at 24, she is in a younger demographic. Donna said that she was a feminist before she came to New Zealand. She had the mentality that "women can do everything and anything a guy does; whether you like it or not, men, we can do it and better”. Donna grew up with strong female influences. However, it was when her mother became ill that she noticed how strong her father was. Donna is also in a unique position. She is a young engineer in a male-dominated industry but has not experienced a lot of gender discrimination. Working in engineering, she has become more liberated in terms of speaking up even though she is a woman, and she is not ashamed of this. Where she disagrees with the feminist movement is in its extremes where women are equal to men and there is no distinction. "The feminist movement sometimes swings us to one end saying we can do it all alone - we don't need a man.” If the feminist movement took less of this stance it would be a more positive movement for Donna. Having strong female influences as a child, Donna appreciates and acknowledges feminist values indirectly. She especially places value on the fact that she has not been discriminated against in her workplace and realises she is in a unique position. Had Donna experienced significant discrimination in the workplace, her views on feminism would very likely have strengthened her feminist principles as she would have experienced firsthand the challenges associated with inequality.

The divisive debates surrounding women in church leadership are not exclusive to churches in New Zealand - it has been a polemic issue for centuries around the world. 
The role of women in the church is a significant issue that affects every Christian woman, either directly or indirectly. Susan represents the majority of respondents when she states, "I am pro women pastors, I am fine with all of that.” All participants believe women bring a different role to the church - something that men cannot contribute. Donna suggests that even if it is not in a pastoral role, women play a vital part in church leadership. They may not be the head of the church but Donna feels that women are important in the foundations of a church. Karen says that in some church structures (that reflect attitudes) there is no platform for women to express some of their gifting. It is portrayed that church is not a place where women should be doing certain things. Karen explicitly states that "we need to change the way we see things". Some of the women in this liberal feminist category are supportive of female leadership in the church. Their views are obviously feminist as they hold that women should have access to the same leadership opportunities as men in the church. Then why do these women adhere to a conservative religion that is perceived as representing traditional gender roles? What is so unique about evangelicalism that it makes liberated women retain membership? It is the ease with which women are able both to be women of faith and to hold their own individual views. Evangelicalism encompasses a flexibility that distinguishes it from other Christian denominations. The importance of individuality within community is what enables evangelical women to express feminist values.

\section{Post-feminism}

Post-feminism broadly encompasses a set of assumptions surrounding the decline in importance of feminism. Post-feminism suggests a more complex relationship between culture, politics and feminism. Feminism is now 'taken into account' but only to be 
shown to be no longer necessary. ${ }^{105}$ Post-feminism represents the perspective of a minority of respondents who feel that feminism is no longer relevant in their lives and were traditional in their views of gender roles. Helen was one of a small percentage of women who was not employed and was a homemaker. She is in the 41 to 54 age demographic and grew up in Malaysia, which may account for her post-feminist thinking. Helen was conservative in her views, stating that she does not think women should be pastors, using 1 Timothy 2:11-15 to justify her stance. She holds that women should not take a spiritual leadership role over men although this does not stop women from teaching women; however, women are not supposed to preach to men. With reference to Paul in 1 Timothy 2:11-15, Sandra explains she does not have a problem with women speaking, but she does remember what Paul says about women keeping quiet in church. Sandra believes that God has made men to be the leaders and women to be the followers.

This post-feminism view throws out feminism and brings tradition back in. It is more than a backlash against feminism; indeed it is a pure rejection of it. However, in their rejection of feminism the women fail to be consistent across factors such as work, home and church. Helen contradicts herself when she states that she does not support women being pastors yet she belongs to a church with a female pastor. Helen's female pastor may lead as a team with her husband but she is not hindered in any way from being in a leadership position in her congregation. Helen's opposition to female pastors, coupled with her commitment to a church with a female pastor, highlights the gap between rhetoric and reality. While she disagrees with female leadership in theory, in practice

\footnotetext{
${ }^{105}$ Angela McRobbie, "Post-Feminism and Popular Culture,” Feminist Media Studies 4:3 (2004): 255264; Yvonne Tasker and Diane Negra, Interrogating Postfeminism: Gender and the Politics of Popular Culture (Durham, N.C.: Duke University Press, 2008).
} 
she does not challenge her church's decision to have a female pastor, nor does she leave her church in objection. Sandra also quotes 1 Timothy2:11-15 but contradictions appear during her discussion on women keeping quiet in the church. Like Helen, Sandra too attends a church with women in leadership. The church services are full of women giving readings, coming up to speak at the podium and leading the men in the worship team. Surely this is a conflict between Sandra's church and the view she holds regarding women speaking in the church? In all other areas Sandra directly encompasses feminist values yet when it comes to church leadership she holds true to traditional gender roles. This demonstrates how Sandra is torn between two different belief systems. On the one hand, she knows what she has read in the Bible and wants to stay true to biblical values; on the other hand Sandra's this-world experience influences her ideas. She sees women leading in the church every day; it is characteristic and she would not challenge it. It is clear that this is what Sandra knows; there is no obvious conflict but an underlying contradiction of beliefs. Furthermore the gap between rhetoric and reality becomes wider in this case.

\section{The Fulfilment of Evangelical Women}

\section{Being a 'Good' Christian}

Barbara believes that much of being a 'good' Christian is your ability to let the Lord teach you gradually. “There is just a goodness to him that doesn't make sense. There is a sense to me that a good Christian goes beyond just getting in the gates of heaven and saying 'oh great, I got in the gates, that's awesome'. It is to understand and allowing God to transform you into Christ likeness - which is the whole point.” Barbara says 
that being a good Christian is essentially about letting God do what he does best and to stop pretending that we as individuals can do anything to change it. Jennifer holds that having God as number one and choosing his paths and his ways is the key to being a 'good' Christian. This is achieved through choosing to build the Kingdom and engage in a relationship with him. She explains that once you have a successful relationship with him you will see success as coming from him. When you follow this Jennifer believes you will always have a good outcome.

For Nancy, the qualities of a 'good' Christian are simple - to read the Bible every day. Nancy places emphasis on the theoretical side of Christianity, whereas Helen explained that being a 'good' Christian is more about doing what the word of God tells Christians to do - they should not merely be listeners, they should be doers. They should be very Christ-like, according to Sandra. She expresses her distress that being a 'good' Christian does not mean that you do certain things and not do others. She says many wrestle with their relationship with God and that this is all part of being a good Christian. "I think that at the end of the day if you still trust and believe in God and you bring people to experience what you have, that's what being a good Christian is.”

While many Christians have differing views on what makes them 'good', evangelicals are unique in that part of their description of what makes a 'good' Christian is their relationship with God. The relationship evangelical women have with God facilitates the decisions they make. The qualities of being a 'good' Christian are the ideals that evangelical women aspire to uphold. In reality some of these ideals are limited as they represent who these women wish to be, not necessarily who they are in their day-to-day lives. Christian women aim to be 'good', ideal Christians - yet most are afraid to voice their religious experiences in a non-Christian context and are adapting their lives to live 
in a secular society. Is what they say superficial or does it really mean something? Generally, the women interviewed had a relationship with God that was individual and significant to them in a very personal way. However, the exuberant nature of their religious practice was not purely characteristic of evangelicalism. The women presented the researcher with an idealistic facade of evangelical religion.

What Do They Still Question?

Despite evangelical women being firm in their faith, most continue to question aspects of Christianity. Of the women interviewed, only one, Michelle, believed that God had done a good job of "straightening that out". She takes the approach that if she cannot figure it out it is alright because God knows what he is doing. At conferences, Michelle often wonders how she can answer difficult questions launched at her. She then says she realised God uses her mouth 90 percent of the time and says that it is not her speaking. “I love that, I don't want to give that away." However, Michelle does admit that there are a lot of people she knows who live faultless lives yet she does not know that they will be in Heaven. This is a tension that Michelle has to negotiate on a daily basis. She has experience in the secular world with non-Christian patients through her work as a psychological therapist. There she must leave her religion aside and this influences her ideas and challenges her faith as an evangelical woman.

The other respondents all wrestled with some components of their faith - some more than others. Ruth struggles on a day-to-day basis with how to share her faith in a postmodern society. She became extremely emotional when she explained her struggle to understand when God can do things and he does not do them. "Why he doesn't act sooner sometimes or seemingly [not] act at all. Not act at all." She believes that 
personal suffering makes you ask questions that perhaps you would not have otherwise. Similarly, Lisa found suffering difficult to come to terms with. She cannot understand why God allows suffering to happen to people who are apparently very good and love God also. She finds it difficult to believe in this as it goes against her expectations. Another aspect Lisa questions is regarding her friends in other faiths that have lives that she thinks are exemplary. She cannot comprehend "the fact that they would go to hell" - she does believe that there is a hell so she finds this concept extremely difficult to negotiate.

Isabella often faces challenges to her thinking but not necessarily to her faith. She considers her faith as something that is so deeply a part of her that no matter what happens there is nothing that would ever stop her loving God. "It's something that's so ingrained in my heart that I could never ever turn away.” There have been a lot of things that have made her angry, such as the passages in 1 Timothy 2:11-15 about the role of women and "the sexist comments that Paul makes in the gospels [sic]". She remembers asking a lot about equality as she had experienced contradictory comments. On the one hand was the perspective of Paul in 1 Timothy 2:11-15 and on the other hand were preachers saying that women are going to be the final stomp on the enemy - "we're to issue the final blow”. As Isabella is involved with Women's Refuge she sees herself as a real vigilante and is a strong advocate for the liberation of women and pay parity. Isabella continues to grapple with her view on homosexuality and says she just does not have an answer for it because "I think that the whole theory of 'love the sinner and hate the sin' doesn't quite equate when the very thing is someone's identity. And how can you love the person, and not who they are? That doesn't make sense to me; I'm still questioning that one”. 
Evangelical women have challenges and they do struggle with some fundamental characteristics of evangelicalism such as the sin of homosexuality and the inerrancy of the Bible. The fact that they question parts of their faith highlights the gap between women's idealistic perception of a 'good' Christian and the challenges they have experienced within evangelical religion. Although evangelical women express a flawless view of life as a 'good' Christian, this is not evidenced as they question aspects of their faith. What makes this idea particularly challenging are the pressures of secular society coupled with evangelical women's desire to be both women of faith and part of the secular world. Evangelical women who want to be established in both a religious world and a secular one will continue to have questions regarding their religiosity as they negotiate the differences between society and faith.

\section{The Best Thing about Being an Evangelical Woman}

Evangelical women pride themselves on their Christianity. They are confident and proud that they are women of faith. Their views may be tainted, however, as they discuss the challenges of being an evangelical woman alongside the idealistic notions of their relationship with God. When asked what the best thing about being an evangelical woman was, each one responded with what was seemingly a rendition of a flawless Christianity. The women interviewed do, however, express a fulfilment different from their secular counterparts. The responses varied in content but the themes were the same - identity, trust, love, belonging and servanthood. Patricia said that being an evangelical woman confirmed her identity. She is fulfilled by God because his love for her is unconditional. The way Patricia lives her life is the ideal - she does not have to rely on anyone for complete acceptance apart from God. "I am valued, I am loved and I have 
worth.” She has a real sense of confidence in the world and for Patricia that is quite a firm foundation to stand on.

Dorothy feels that the most rewarding aspect about being an evangelical woman is her relationship with Jesus, God and the Holy Spirit - this is not a relationship that she can have with anyone else. Dorothy receives daily reward from living in an intentional Christian community; one of the things she loves about being a 'follower of Jesus' is that she can live her life alongside others, offering and receiving support and servanthood. The sense of belonging in a Christian community, whether it is a housing complex or the church itself, was discussed by Ruth. She felt the best things about being a Christian were that there is purpose and meaning. There is a story about why we're here and where we're going and to Ruth things all make sense. She is loved and she belongs.

Being a Christian is very much a part of Laura's identity. For her it goes much deeper she went through childhood to adolescence having known God and was convinced that she was loved by him. By the time Laura was through her teenage years she was no longer afraid of death and she knew that she was forgiven. Laura now really believes in the power of prayer. “People always said it but now I have a sense that, I can’t explain, I just feel so wrapped around with love. The best thing about being a Christian? The confidence that I am loved. That's all. That - whatever else happens - is harnessed in your life and in the banal there is this sparkle. I'm loved.”

The positives for being a woman of faith are clearly illustrated by the participants. But is this enough for them in New Zealand society? Through this research it has been discovered that there is a significant gap between rhetoric and reality with regard to the 
conflicts evangelical women face. They have ideals about what the evangelical experience presents them with, yet they still have a desire to be a part of secular society and negotiate the challenges that come with it. This does not always transpire according to plan - as women attempt to negotiate these challenges, crossing from secular to religious life and back again, contradictions appear in their views. Demographics reveal similarities and differences between the women - generally the younger demographic is more liberal in its feminist thinking and places significance on equal rights, pay equity, shared domestic labour and childcare. Furthermore, the small percentage of women who stay at home compared with women who work outside of the home tends to be more conservative about gender roles. Evangelical women are fulfilled in their religious life; however this does not detract from the negotiations they have to make. 


\section{CHAPTER FIVE}

\section{DISCUSSION}

At some time in your life, you've got to face up to the f-word. ${ }^{106}$

\section{Introduction}

Global evangelicalism is a varied and growing phenomenon. Evangelicals are diverse in all demographics such as culture, age, sex and ethnicity, and different churches cater for different groups. The evangelical movement in New Zealand may seem to the outsider as small, insignificant and lacking relevance; however within the old warehouses or purpose built complexes is a bustling sub-culture of evangelical New Zealanders worshipping Jesus and experiencing the Holy Spirit. New Zealand is amidst an evangelical revival. ${ }^{107}$ We are seeing development and growth not only in evangelical institutions but in their church attendance figures as well. ${ }^{108}$ Women contribute significantly to church development - Michelle stated that her church congregation was 70 percent women. There is an apparent conflict between the role women have in both church and society as evangelical women grapple with how to be a woman of faith in a post-modern society. Thus it is necessary to research the growing phenomenon of women in evangelical institutions.

\footnotetext{
${ }^{106}$ Dr. Naomi Hersom quoted in Bob Harvey, "Educator says Christianity and Feminism Go Together," The Ottawa Citizen, 27 January, 1990, I.6.

107 John M. Hitchen, "What It Means to be an Evangelical Today - An Antipodean Perspective: Part One - Mapping Our Movement,” EQ 76:1 (2004): 47-64.

108 Pentecostals were the only major Christian group in New Zealand to experience significant growth between 1991 and 1996, with their numbers increasing by 55 percent. This included Born Again which is now included in Evangelical, Born Again and Fundamentalist. "Religion and Ethnicity Source: New Zealand Official Yearbook 2000,” http://www2.stats.govt.nz/domino/external/web/nzstories.nsf/0/553e95d870abb153cc256b1e0080ad44?O penDocument (accessed 19 May, 2010).
} 
For centuries women have paved the way to enable liberation for future generations. Religious institutions have been perceived to stand in the way of the liberation of women - making women feel as though they have an obligation to support their faith rather than pursuing their liberation. However, religious institutions that do not change inevitably decline; the churches that survive and grow will adapt to contemporary culture. ${ }^{109}$ Richard Quebedeaux argued that evangelicalism's engagement with the world is 'liberalising' the tradition culturally and theologically. Evangelicals are becoming more educated, middle class, ecumenical, feminist, focused on social justice, less tolerant of racism and less homophobic. ${ }^{110}$ Evangelical women who identify with feminism are not simply 'selling out' to popular culture, they are refining their ideas and developing in a way evangelicalism allows them to do - to have individual opinions in a communal institution.

A closer examination into the lives of evangelical women in New Zealand reveals ideological contradictions and the profound impact of feminism on a religious subculture that has traditionally resisted gender equality. As the secular world holds its position, the distance between feminism and evangelicalism becomes shorter. Traditionally it was argued that the Bible teaches not only that men and women are created with different skills and abilities, but also that men are created to be leaders and initiators in family life while women are created to be nurturers and submissive followers. ${ }^{111}$ In today's society it seems that cracks have developed in this dominant ideology which may be due to the appearance of feminism in evangelical circles.

\footnotetext{
${ }^{109}$ Donald E. Miller, “Hope Chapel: Revisioning the Foursquare Gospel,” in The Annual Meeting of the Society for the Scientific Study of Religion (Washington, DC., 1992).

${ }^{110}$ Richard Quebedeaux, The Worldly Evangelicals (San Francisco: Harper and Row, 1978).

111 John Bartkowski, Remaking the Godly Marriage: Gender Negotiation in Evangelical Families (New Brunswick, N.J.: Rutgers University Press, 2001).
} 


\section{Major Findings}

The results reveal two significant findings regarding evangelical women in New Zealand. Firstly there is a gap between rhetoric and reality in the lives of evangelical women. Although this is not a universal gap, what is apparent from this research is the basic way in which the evangelical interviewees speak of traditional biblical gender roles in terms of male headship and female submission in theory while in the practice of their day-to-day lives this concept does not follow through. John Bartkowski similarly found this in his study on evangelical families. He found that a common relational strategy employed by evangelicals was to adhere publicly to the dominant essentialist and patriarchal discourse that they hear in church while turning to more egalitarian strategies for household tasks, child rearing and decision making. ${ }^{112}$ This is significant because of the importance evangelical commentators place on consistency - a theme that re-occurred through this research - of holding evangelical truths inside and outside of the church parameter. This theme of consistency applies to male headship as some leading evangelical scholars place significance on the role of the man having authority.

Wayne Grudem quotes 1 Timothy 2:12, "I do not permit a woman to teach or to exercise authority over a man; rather she is to remain quiet." He suggests that evangelical feminists give an alternative meaning for 'exercise authority', but in doing so they chip away at God's word, in effect removing God's words from verse after verse in the Bible. ${ }^{113}$ Thus for Grudem consistency is vital as it is an issue of inerrancy. What has been discovered through this research is that this is not always the doctrine that is followed. Alternatively, in post-modern terms, evangelical women are

\footnotetext{
112 John Bartkowski, Remaking the Godly Marriage: Gender Negotiation in Evangelical Families (New Brunswick, N.J.: Rutgers University Press, 2001).

${ }^{113}$ Wayne Grudem, Evangelical Feminism: A New Path to Liberalism? (Wheaton, Illinois: Crossway Books, 2006), 199.
} 
empowered by their role as post-modern women in a society of choice. Gender empowerment is one of the main procedural concerns when addressing human rights and development and is thus a significant factor in establishing women's role in society.

Similarly this research found that many of the evangelical women interviewed lived in two distinct worlds. Women have chosen to be part of a conservative religion and simultaneously to identify with feminism - they are involved with secular society through their employment and they also take control of their family life. In today's society, evangelical women have been exposed to the post-modern woman - they may not want to encompass all values that come with this image but they do not want to be left behind an ever-changing society. This exposure has led evangelical women to live in two worlds as they want to be a part of these societal changes and contribute to them while at the same time be evangelicals. Women expressed a drive towards commitment to their husbands or their goals for married life. This led to a traditional gender role in the home and thus they shared the obligations that needed to be fulfilled. This role was met with an alternative perspective where women still wanted to have equal rights as their husbands such as equal decision making, managing finances and shared childcare. Ethnicity does not appear to be a factor that has a significant impact on whether or not evangelical women identify with feminism. As only one Chinese Malay woman is in the post-feminist category and the others are in the liberal feminist category, it shows that generally these women do have feminist values although simultaneously they do place some importance on tradition through the Bible. The Chinese Malay women are not more or less feminist in general than other ethnicities.

Evangelical women exercise a significant amount of autonomy which is reflected in their views of feminism and experiences as women. This autonomy can be seen in 
family life, social life and the workplace. Women can take control of the family finances, they can assume the role of breadwinner and they can have all of the educational and employment opportunities that a secular woman can access. This example demonstrates the two separate worlds evangelical women must live in - their obligation to evangelical faith combined with the influence of secular liberal society.

Evangelical women directly and indirectly value feminist principles. This leads to inconsistencies between the seemingly contradictory choices they have to make between church and secular society. This is balanced by women supporting traditional gender roles within the symbolic boundaries of the church, yet at the same time embracing feminist roles outside of those boundaries - in the workplace or in wider society. Of the evangelical women who expressed traditional views regarding feminism, all continued to espouse feminist values, such as the importance placed on pay equity, women's role in the church and the impact of feminism on Christianity and wider society. Evangelical women appear to embrace feminist values even if they are hostile towards the label of feminism itself. On the one hand there is loyalty towards faith. On the other hand evangelical women are driven to be modern women who also have faith. This causes conflict with issues such as women in church leadership, abortion, homosexuality and the 'woman as nurturer' role. Through this research these issues have been challenged and evangelical women have expressed conflicting viewpoints. It is clear that women are unsure about which world to be part of so they have developed ideals from both secular society and evangelical faith.

The selling point of evangelicalism is its focus on individualism and contemporary society. It is not giving itself away to popular culture - instead evangelicalism is reflecting the needs of a changing audience. It has dampened down the debate on 
women that threatened to divide a religious subculture intent on maintaining both its orthodox core and its broad appeal. ${ }^{114}$ It is this view which makes evangelicalism so popular with women today. This is why so many women make up the larger group in evangelical congregations and why their membership is retained. Women are attracted to a faith where they have the ability to be a part of a fluid religious movement - it moves with popular culture and continues to influence women today. Margaret Bendroth was somewhat baffled at what brings women to conservative Christianity and, consequently, what keeps them there. She suggested that women in the movement experienced a clear call to Christian vocation and used a language of cultural critique that simplified the daunting range of choices in a secular lifestyle. Women appreciated the movement's high standards for family life. Women's stake in the success of the conservative movement was at least as strong as the ambitions that drove its masculine leadership. ${ }^{115}$ It seems that women are drawn to conservative religion through its ability to order realities while allowing for complex and varied performances of individuality. There remains, however, a tension between feminism and evangelicalism which, when examined with stereotypical representations, becomes reasonable. However, beneath the surface of these two worlds in which evangelical women attempt to negotiate they find themselves on common ground.

\footnotetext{
${ }^{114}$ Sally K. Gallagher, Evangelical Identity and Gendered Family Life (New Brunswick, N.J.: Rutgers University Press, 2003).

${ }^{115}$ Margaret Bendroth, Fundamentalism and Gender: 1875 to the Present (New Haven, C.T.: Yale University Press, 1993), 11.
} 


\section{Significance of Findings}

Society is a large social grouping that shares the same geographical territory and is subject to the same political authority and dominant cultural expectations. It is thus a significant influence upon the individuals within it. The influence of the post-modern society cannot be avoided and it is similarly having an effect on evangelical women as well. The research findings demonstrate the relationship between feminism and evangelicalism, showing their compatibility rather than their animosity. It is important to understand that these two phenomena are not at war as historically thought and in today’s society it is significant to recognise attitudinal change. Phil Johnson disagrees and suggests that this change in culture and the influence of post-modern society that is detrimental to evangelicalism. He states that the gospel's most dangerous earthly adversaries are church leaders who cultivate a gentle, friendly, pious demeanour but hack away at the foundations of faith under the guise of keeping in step with a changing world. ${ }^{116}$ The reality is that evangelicalism is changing and because of this culture adaption the movement is retaining membership and increasing in opportunities for women. Evangelical women have benefitted from this change in culture as they can successfully live in two worlds. But it is not without conflict, and often women have to negotiate the differences between these secular and religious worlds. However, this serves to highlight the importance of the role of women and feminism within evangelicalism. To recognise this is valuable and important to students of contemporary religion because today evangelical women have a different perspective of their role.

What happens in society is often generally be reflected in the church; as women in a secular setting have risen to leadership and equal opportunity, women in the church

116 Phil Johnson, “The Neo-Liberal Stealth Offensive,” (2010), http://www.9marks.org/ejournal/byauthor/phil-johnson (accessed 13 December, 2010). 
expect the same. Faith does not prevent evangelical women from achieving anything in their chosen fields of work and activity. Although they may adhere to a conservative religion which is perceived as encompassing traditional gender roles, these women continue to have goals and aspirations. Autonomy - part of the ideology of empowerment - is a significant part of who these women are. Autonomy is the key function for evangelical women in all spheres of life. It enables them to express meaning and value in both religious and societal contexts. Valerie Saiving, in her 1960 groundbreaking article on feminist theology and gender identity, claimed that women of faith value their femininity. "They do not wish to discard their sexual identity but rather gather it up into a higher unity. They want, in other words, to be both women and full human beings." 117 Evangelical women are now in a position to challenge the norm and go beyond tradition to explore the secular world full of different, yet not always ideal, worldviews, communities and opportunities. This is significant because in a country such as New Zealand, which is becoming more secular and identification with Christianity is showing an overall decline, tolerance and acceptance of other worldviews is imperative for a functioning society. ${ }^{118}$

The debates over female submission emphasise the gap between rhetoric and reality within the evangelical cultural repertoire. In today's post-modern society there is increasing flexibility in the interpretation and meaning of submission. Bartkowski suggests that while submission is clearly an evangelical cultural tool, the meaning of this term is flexible enough within the religious subculture to accommodate complementarian norms as well as more egalitarian convictions. Evangelical debates

\footnotetext{
${ }^{117}$ Valerie Saiving, “The Human Situation: A Feminine View,” Journal of Religion 40 (1960): 100-112. ${ }^{118}$ Comparison of 2001 and 2006 Census figures shows an overall decrease in people affiliating with Christian religions. Statistics New Zealand (2006), "QuickStats about Culture and Identity," http://www.stats.govt.nz/Census/2006CensusHomePage/QuickStats/quickstats-about-a-subject/cultureand-identity/religious-affiliation.aspx (accessed 2 June, 2010).
} 
over the word 'submission' allow women to understand it differently, such as the wife's responsibility or as the couple's mutual obligation, without challenging their shared commitment to evangelical Christianity. Discursive debates among evangelicals help to facilitate ideological diversity at the grassroots of this religious subculture. ${ }^{119}$ The gap between rhetoric and reality allows for blurred distinctions between complementarian and egalitarian views. This makes defining groups of evangelical women difficult unless their lives are closely studied. On the surface there is a focus on complementarian values; however, in everyday experience a more egalitarian pattern emerges. Similarly, Bartkowski shows that cracks have developed in the dominant ideology of essentialism (the belief that men and women are inherently and naturally different), as feminist evangelicals have argued that men and women are inherently equal. Although this position still relies on the logic of essentialism, it allows evangelicals to stake out an oppositional position in which mutuality is considered normative for married couples. ${ }^{120}$ Evangelical women choose to have the gap between rhetoric and reality. It is not forced in any way and evangelical women do not appear to be oppressed. The reality is that in New Zealand they are happy and fulfilled living in two worlds. Women are facilitating change within popular culture while maintaining their ties to traditional religion. Just as religious institutions that do not change lose relevance, individuals that do not adapt to the changing nature of society will stop growing and developing within it. Evangelical women have the freedom to take what opportunities the gap offers and can live in two worlds. With an obligation to tradition within church and family life and liberation and feminism outside of church life, it seems evangelical women in New Zealand can have it all.

\footnotetext{
119 John Bartkowski and Jen'nan Ghazal Read, "Veiled Submission: Gender, Power, and Identity among Evangelical and Muslim Women in the United States,” Qualitative Sociology 26:1 (2003): 71-92.

120 Stephen Ellingson, "Review: Remaking the Godly Marriage: Gender Negotiation in Evangelical Families by John Bartkowski,” Sexuality Research and Social Policy Journal of NSRC 2:1(2005): 68-70.
} 


\section{Alternative Meaning of Findings}

Two factors could have altered the findings but could not be included within the scope of this research. The influence of both family and persons of leadership could affect the perspectives of evangelical women. A careful longitudinal study of Americans has shown that by adolescence most children have a partisan identification connected to political preferences in the same manner as adults. Among those children who have a partisan preference, nearly all share it with their parents. ${ }^{121}$ Similarly, the influence of parents' political views on children's voting habits is a phenomenon that has been widely researched, confirming the impact of parents' views. Parents not only influence their children's views on politics, they have a significant effect on the way children perceive gender roles. Studies show that children at two and a half years of age use gender stereotypes in negotiating their world and are likely to generalise gender stereotypes to a variety of activities, objects and occupations. Children even deny the reality of what they are seeing when it does not conform to their gender expectations. ${ }^{122}$ In this study, had questions been asked about women's parents and the role that they played in shaping their religious views, the results may have looked somewhat different. This study may have found that women are significantly influenced by the religious views of their parents, and this could be one of the reasons for their ongoing commitment to the church. From the studies on parental influence it seems likely that some of the women would have been influenced by the faith decisions and gender roles that their parents valued.

\footnotetext{
${ }^{121}$ Christopher H. Achen, "Parental Socialisation and Rational Party Identification," Political Behavior 24:2 (2002): 151-170.

${ }^{122}$ Susan D. Witt, "Parental Influence on Children's Socialization to Gender Roles," Adolescence 32 (1997).
} 
In a similar vein, the role of persons in leadership and the direct influence of leaders, such as mentors in the academic setting, affect the perspectives of evangelical women. The majority of women in this research were highly educated and had achieved some form of tertiary level study. Therefore it is interesting to highlight the research by Nicola Hoggard-Creegan and Christine Pohl as they discovered unique and not always successful relationships between academic mentors and female evangelical students. Male mentors dominated among Hoggard-Creegan and Pohl's participants, and they tended to be relationships of either support and encouragement or of confusion and distance. ${ }^{123}$ As mentors play such a distinct role in shaping the identities of academic evangelical women, research into this relationship would produce alternative findings for this study. Had women been influenced in a positive light by their mentors, they would have the potential to hold more egalitarian views with their confidence being enhanced and more support and encouragement given for them to succeed as evangelical women. It would be less likely that there would be such a gap between rhetoric and reality because women could be inspired and encouraged by mentors and thus be more likely to exercise their gifts. It could become apparent that had the women interviewed for this research had positive mentors for academic study, they would be more likely to embrace feminist values. On the other hand, if women were mentored by a male who was negative or not as supportive, this could reflect differently in the findings and might discourage evangelical women from being so outspoken about their views on women's role in both the church, family and wider society.

\footnotetext{
123 Nicola Hoggard-Creegan and Christine Pohl, Living on the Boundaries: Evangelicalism, Women, Feminism and the Theological Academy (Illinois: InterVarsity Press, 2005), 79.
} 


\section{Limitations}

This research clearly shows the perspective of women in evangelical churches. It illustrates their struggles with living in two separate worlds, their aspirations for women in church leadership and their role in the home with their family. This research has attempted to give a snapshot of evangelical women's priorities and ideals in a postmodern world. What is less clear is how evangelical women interact with men on a daily basis. They discussed their husbands in the interviews; however, the opportunity never arose to witness the interaction between husband and wife, which can be a crucial observation. Would women open up the same way if their husbands were sitting beside them? Would their husbands agree with their views on headship and feminism? What has not been explored is how men respond to feminist values or what their perspectives are on women's role in the church and in the family. It is difficult to know whether the participants' husbands would agree with what their wives were discussing and this was not investigated. Although it would have provided an interesting avenue for research, the motivation behind men being excluded was because it would have significantly increased the scope of this research and the data would have become unmanageable. There was already a large amount of rich data from interviewing 20 women. Since the data is specific to Wellington and Hamilton in New Zealand it is difficult to generalise the results.

The nature of qualitative research is that in any study there are limitations that are difficult to regulate, yet must be addressed. This study has explored a wide range of women from differing demographics; however the method of participant selection had its limitations. As a consequence the overall diversity among participants is not immense. There is variation between the locations of the churches as well as their 
ethnicity. Lighthouse Christian Fellowship in Hamilton consists mainly of Asian immigrants, whereas The Rock and Lifepoint in Wellington had a majority of European Pakeha congregants. It was fortunate that the women interviewed represented different age groups, ethnicities, incomes, employment and religious upbringings. The validity of the research findings is not compromised because of this limitation, but it is important to acknowledge that the results of this research are somewhat affected because the majority of the participants are well educated, have medium-to-high household incomes and are of European Pakeha descent. Research does suggest however that this demographic is overly represented in evangelical institutions. ${ }^{124}$ Although this demographic constitutes the majority in evangelical churches, it does not overly hinder the validity of this research as the primary focus is evangelical women. What is significant is that all the woman, despite the demographics, have provided details about their lives and the experiences they have had growing up, in their home life and their church.

As a qualitative method, interviewing can be a time-consuming, exhausting and challenging exercise. The interview process for this research was extremely timeconsuming as many participants had their own priorities and commitments. Those who were mothers had to work around their children and those who worked full-time had to negotiate times around church, appointments and employment. As the length of the interviews was varied, this created a small imbalance of information as there were large amounts of data from some women and less from others. Interviews can be a difficult process. Some participants were naturally comfortable in the interviewing situation and thus expressed their opinions freely and frankly. There were other women who were

\footnotetext{
${ }^{124}$ Heather Hendershot, Shaking the World for Jesus: Media and Conservative Evangelical Culture (Chicago, IL: University of Chicago Press, 2004).
} 
well-aware of the tape recorder and seemed less comfortable with the interviewing situation. The women were relaxed about being recorded but the recorder may have made the situation more formal than anticipated. For example, some of the women would engage in casual and friendly conversation with the recorder off, but when the recorder was turned on their demeanour changed and they were distanced. Some women would reveal more information about themselves than others did. A limitation with this type of study is that a complete stranger wants to know many personal details about the participant's life - something difficult for many individuals. When discussing sensitive topics regarding personal information, some women did not want to go into detail. The researcher continued to probe with these women but, when asked, the participant backed away from the questions. Therefore there could have been some rich data that was missed. This is one of the known limitations when using human participants for research - the researcher is unable to control how much information participants are willing to discuss.

\section{Recommendations for Future Research}

Based on the results of this study, there are several recommendations for future research. Some of the limitations outlined in this study - such as the majority of respondents being of European Pakeha descent and the issue of some women observed to be less comfortable in a formal interview situation - may be minimised or eliminated in a revised examination of evangelical women within their respective churches in New Zealand. In order to improve or verify the accuracy of the results a nationwide study of women and men in evangelical churches in New Zealand would be appropriate. This 
research focused on two locations; an extended study of churches in the main centres around New Zealand would provide a deeper examination into women in evangelical churches. This would allow for a comparative study and it would be more straightforward to generalise the study to wider New Zealand. A national survey would help to identify the trends among the churches based on geographic location and thus could verify the findings from this research. This would be a considerable and immense project to undertake, which is why it is not within the scope of this research.

This study only begins to delve into the lives of evangelical women in New Zealand. Evangelical feminism is an expansive subject, one that requires investigation into the processes and development of women of faith. There are many avenues that have the potential to be explored using this research as a foundation as this research merely scratches the surface regarding women within the evangelical movement. Some unanswered questions have developed during this research that would be a significant starting point for future studies. One question of interest is about the men of evangelicalism. Further research into the lives of New Zealand evangelicals could ascertain who these men really are and question whether they support the views of their female counterparts. This would be significant research as it would determine the perspectives o the themes in this research of a broader evangelical circle, not just women. It would have been beneficial to have interviewed men from the churches examined in this research to develop a deeper understanding of the role of evangelical women and how they interact with men. Furthermore, the husbands of the married women who were interviewed would have been a useful case study to test whether the views of the husband and wife were aligned. This would produce some fascinating results. When deciding on a research subject, there was potential for many different 
factors that paralleled this study as well as a vast number of positions to pursue. To reduce the scope of this research some of these areas had to be limited. For example, it would have been significant to conduct a comparative study of women who grew up in the evangelical church versus women who converted to evangelicalism at a later age. This would develop an understanding of the potential differences in ideals and priorities that evangelical women have. Further research into the age demographic would be significant to show the differing views of feminism and gender roles. It is hoped that this research is a starting point for further study and a motivation for the development of scholarship on evangelical women and evangelicalism in general in New Zealand.

\section{Conclusion}

At the centre of evangelical feminism is biblical authority, its nature, meaning and scope. From the beginning, evangelical feminists addressed biblical authority which was motivated by a desire to convince other evangelicals that the Bible, not just secular society, teaches the equality of men and women in the home, church and society. As a result of these efforts evangelical feminism erupted globally in evangelical circles and scholarship. New Zealand evangelicals were not among those influenced by this phenomenon. Evangelicalism is now different. As a movement it has changed and is constantly adapting and developing along with the way that secular society moves. This is how evangelicalism has remained relevant and able to retain large congregations. When examining the diverse number of arguments, ideas and academic debates such as that between complementarianism versus egalitarianism, the evolving nature of evangelicalism is difficult to dispute. Through this research it has been discovered what it means to be an evangelical woman in the context of changing New Zealand society. 
This snapshot has revealed many interesting findings, illustrating the often contradictory and challenging aspects that evangelical women must face as they identify with feminism as a secular symbol and maintain a conservative evangelical faith. This study comparing feminists and contemporary evangelical women suggest both cultures are distinctive yet overlapping. This allows for the two movements to intersect and for evangelical women to draw out values of each as they deem appropriate for their use in negotiating the world.

Evangelical women in New Zealand today are living in two worlds. The women have a strong sense of identity and faith within evangelicalism. However, simultaneously there is a contradictory strong influence of secular liberal society which is evident through the women's identification with feminist values. From the outside, the perception is that evangelicalism and feminism are not compatible and are in fact two polemic movements. However this is not representative of the evangelicalism portrayed in this research. What has been discovered is that evangelical women can successfully live in two separate worlds - one secular and one religious. They can be women of faith while at the same time they can live in a secular society.

Overall evangelicals do not react quite as negatively towards feminism as was once the case. As more people within the church have recognised the truth in some of the feminist arguments there has been a change in attitudes and a willingness to listen. The feminist movement has brought with it ideas and challenges that have influenced evangelical women. This research brings to light the new pressures evangelical women face. It highlights the contradictions in their values regarding, for example, female submission and the role of women. Although feminism may in some cases be contested by the evangelical women interviewed, all participants identified with feminist values 
either directly or indirectly. The expression of a woman's perspective is facilitated in part by a feminist identity. What causes this gap between rhetoric and reality is a desire to be committed in faith and have Christian support systems as well as an aspiration to be unique in that they can adapt and embrace a secular culture simultaneously.

What has been discovered is that evangelical women in New Zealand are living in two worlds - one loyal to religious faith and one liberalised by secular society - that significantly impact their identities and the way in which they interact with the world. Similarly there is a significant gap between rhetoric and reality in evangelical women's lives. These challenges are defined by society and thus are a useful tool to help understand the conflicts evangelical women have to negotiate. The tension between the two worlds highlights the disparity evangelical women face. The issue here is that women want the best of both worlds; however, at the same time they are critical of the secular world in which they find themselves. This contributes to the findings that illustrate the flexibility and lack of strict doctrine within evangelical circles. There is a gap between rhetoric and reality in evangelical women's lives in New Zealand which signifies a change in the way religious institutions are functioning within the context of a post-modern secular society. This change is reflected in women's desire to question gender roles within an evangelical context, aligning themselves with the view that ‘evangelical women can do anything’. Evangelical women have a new-found autonomy and this has become an ideology for their empowerment. 


\section{APPENDIX I}

Demographic Survey

\section{Age}

2. Occupation

3. Marital Status (circle one):
a. Never married
b. Married
c. Divorced or separated
d. Widowed

4. Children
a. How many?
b. Age range?

5. Education (circle highest level completed):
a. High school
b. Attended college
c. Bachelor's degree
d. Postgraduate degree

6. Household Income (circle one):
a. Under 20,000
b. 20,000 to 39,999
c. 40,000 to 69,999
d. 70,000 to 99,999
e. 100,000 plus

7. What religious denomination were you raised in?

8. When did you become an Evangelical Christian? (circle one)
a. As a child
b. As a teenager
c. As an adult
d. Through marriage

9. How long have you belonged to this church? 


\title{
APPENDIX II
}

\author{
Interview Schedule ${ }^{1}$
}

1. Tell me about yourself

a. Your childhood (Place of birth? Parents and siblings? Religious upbringing?)

b. Your education and work experience

c. Your current marriage situation (Married? Children?)

2. How/when did you become an Evangelical Christian?

a. What was the reaction of your family/friends?

b. Why did you join this church?

3. Tell me about your life as an Evangelical Christian

a. Since you committed to your faith what aspects of your life (friendships, relationships, career plans) have changed and which have remained the same?

b. On a daily basis, are you mostly in contact with other Christians?

c. Who are your closest friends?

d. What does being a good Christian mean to you?

e. Are there aspects of your faith that you have questions?

f. What do you think are the most important issues facing Christian women today?

4. What roles should women play in New Zealand society?

a. Do you think it is a good thing when women go into traditionally male occupations like engineering or the military?

b. Do you think New Zealand would benefit if more women were elected to parliament or promoted to leadership positions in large businesses?

c. Do you think gender discrimination/sexual harassment is a real problem?

d. Do you support laws mandating equal rights for (or prohibiting gender discrimination against) men and women?

5. How do you feel about women's role in the church?

a. Do you think women should be Pastors?

6. What do you feel are the proper roles for men and women in the Christian family?

a. Do you consider the man as the head of the family?

b. Should the man have the final say in family decision-making?

c. Do you feel you should submit to your husband? What does this mean? Can you give examples of how this plays out in your daily life?

d. Do you feel a woman should stay at home with the children while the husband supports the family?

\footnotetext{
${ }^{1}$ The interview schedule was a guide for the researcher - actual questions asked may have varied from this transcript.
} 
e. Does your husband help with child rearing/domestic tasks?

f. Homemakers: How did you feel about quitting job/career?

g. Working women: How do you manage a job and kids?

h. Single women: Are you looking to (re)marry? What do you look for in a man?

7. Social Issues

a. How would you assess the impact of the women's movement on New Zealand society?

b. Has the women's movement had any impact on Christianity?

c. How do you feel about abortion? Contraception? Homosexuality?

d. Have you taken action on either of these issues?

8. Secular Society

a. What experiences have you had living in a society that is seen as secular?

b. Are there any challenges you have faced from non-Christians in New Zealand society?

c. Do you believe Christian women have conflicts between their role in their church and their role in wider society? Explain.

d. Overall, what would you say are the most challenging or difficult aspects about being an Evangelical Christian woman in today's society? Which are the most rewarding? 


\section{BIBLIOGRAPHY}

Achen, Christopher H. "Parental Socialisation and Rational Party Identification." Political Behavior 24:2 (2002): 151-170.

Adell Cook, Elizabeth, and Clyde Wilcox. "Feminism and the Gender Gap - A Second Look.” The Journal of Politics 53:4 (1991): 1111-1122.

Alive Magazine. www.alivemagazine.com.au (accessed 10 April, 2010).

Alumkal, Antony W. "Preserving Patriarchy: Assimilation, Gender Norms, and SecondGeneration Korean American Evangelicals.” Qualitative Sociology 22:2 (1999): 127140.

Andrew, M. E. Responding in Community: Reforming Religion in Aotearoa/New Zealand. Dunedin, N.Z.: Faculty of Theology; University of Otago, 1990.

Anonymous. "Is Rapprochement Possible Between Unreconstructed Liberalism and Contemporary Conservative Evangelicalism?” Evangel 25:3 (2007): 68-72.

Armerding, Hudson T. "The Evangelical in the Secular World.” Bibliotheca Sacra 127:506 (1970): 129-139.

Aune, Kristin. “Evangelical Christianity and Women’s Changing Lives.” European Journal of Women's Studies 15 (2008): 277.

Aune, Kristin. "Much Less Religious, A Little More Spiritual: The Religious and Spiritual Views of Third-Wave Feminists in the UK.” Feminist Review 97 (2011): 3255.

Barna Group. "Who is Active in 'Group’ Expressions of Faith? Barna Study Examines Small Groups, Sunday School and House Churches.” www.barna.org/faith- 
spirituality/400-who-is-active-in-group-expressions-of-faith-barna-study-examinessmall-groups-sunday-school-and-house-churches? $q=$ =church+attendance $\quad$ (accessed 10 December, 2010).

Barrs, Jerram. The Heart of Evangelism. Wheaton, Illinois: Crossway Books, 2001.

Bartkowski, John. Remaking the Godly Marriage: Gender Negotiation in Evangelical Families. New Brunswick, N.J.; London: Rutgers University Press, 2001.

Bartkowski, John, and Jen’nan Ghazal Read. “Veiled Submission: Gender, Power, and Identity among Evangelical and Muslim Women in the United States.” Qualitative Sociology 26:1 (2003): 71-92.

Bartkowski, John, and Lynn M. Hempel. "Sex and Gender Traditionalism among Conservative Protestants: Does the Difference Make a Difference?” Journal for the Scientific Study of Religion 48:4 (2009): 805-816.

Bendroth, Margaret. Fundamentalism and Gender: 1875 to the Present. New Haven, CT.; London: Yale University Press, 1993.

Bhandari, Lok M. “Defining Evangelicalism’s Boundaries Biblically, Historically, Theologically, Culturally, and in Ministry in the $21^{\text {st }}$ Century.” ERT 26:4 (2002): 292209.

Bible, The. New Revised Standard Version. London; Canada; India; Australia; New Zealand: HarperCollins Publishers, 1989.

Bloesch, Donald G. “Evangelicalism,” DIALOGUE: A Journal of Theology 47:1 (2008): 16-20.

Bradshaw, Matt, and Christopher G. Ellison. "The Nature-Nurture Debate Is Over, and Both Sides Lost! Implications for Understanding Gender Differences in Religiosity.” Journal for the Scientific Study of Religion 48:2 (2009): 241-251. 
Braidotti, Rosi. "In Spite of the Times: The Postsecular Turn in Feminism.” Theory, Culture \& Society 25:6 (2008): 1-24.

Brasher, Brenda E. Godly Women. New Brunswick, N.J.; London: Rutgers University Press, 1998.

Breward, Ian, ed. A History of the Churches in Australasia. New York; Oxford: Oxford University Press, 2001.

Brown, Colin. Forty Years On: A History of the National Council of Churches in New Zealand. Christchurch, N.Z.: The Council, 1981.

Brown, Ralph. "Evangelical Social Thought.” The Journal of Ecclesiastical History 60:1 (2009): $126-136$.

Bruland, Esther Byle. "Evangelical and Feminism Ethics: Complex Solidarities.” The Journal of Religious Ethics 17:2 (1989): 141-42.

Bryant, Alyssa N. "Assessing the Gender Climate of an Evangelical Student SubCulture in the United States.” Gender and Education 18:6 (2006): 613-634.

Bryson, Gary; Mark Noll, Alan Anderson, Mark Hutchinson, Cheryl Catford, Tim Costello and Brian Houston. "Encounter: It's a God Thing: The Rise of the Mega Church.” ABC National Radio, 24 April, 2005.

Buchegger, Jürg. "Evangelical Feminism and Biblical Truth: An Analysis of More than 100 Disputed Questions/Recovering Biblical Ministry by Women: An Exegetical Response to Traditionalism and Feminism.” Evangelical Review of Theology 32:3 (2008): 275-277.

Bullough, V. L. The Subordinate Sex: A History of Attitudes towards Women. Champaign, IL: University of Illinois Press, 1974. 
Bunkle, Phillida, and Beryl Hughes, eds. Women in New Zealand Society. Auckland; Boston: Allen and Unwin, 1980.

Burgess, Michael. "Dimensions of the Faith: A Shaping of Evangelicalism.” ERT 29:1 (2005): 16-31.

Butler, Judith. Gender Trouble: Feminism and the Subversion of Identity. New York; London: Routledge, 1990.

Butler, Judith. Undoing Gender. New York; London: Routledge, 2004.

Campbell, Douglas A., ed. Gospel and Gender: A Trinitarian Engagement with Being Male and Female in Christ. London; New York: T\&T Clark International, 2003.

Carmody, Denise Lardner. Biblical Woman: Contemporary Reflections on Scriptural Texts. New York: Crossroad, 1988.

Carmody, Denise Lardner. Feminism and Christianity: A Two-Way Reflection. Nashville: Abingdon Press, 1982.

Chopp, Rebecca S., and Sheila Greeve Davaney, eds. Horizons in Feminist Theology: Identity, Tradition, and Norms. Minneapolis; Kitchener: Fortress Press, 1997.

Christian Woman. www.christianwoman.com.au (accessed 10 April, 2010).

Christians for Biblical Equality. "Better Together.” Conference Recordings, Melbourne, Australia, June 2010.

Christians for Biblical Equality International. www.cbeinternational.org (accessed 24 February, 2010).

Cochran, Pamela D. H. Evangelical Feminism: A History. New York, London: New York University Press, 2005. 
Colaner, C. W., and S. C. Warner. "The Effect of Egalitarian and Complementarian Gender Role Attitudes on Career Aspirations in Evangelical Female Undergraduate College Students.” Journal of Psychology and Theology 33 (2005): 224-9.

Coleman, Jenny. “An Introduction to Feminism’s in a Post-Feminist Age.” Women's Studies Journal 23:2 (2009): 3-13.

Collett, Jessica L., and Omar Lizardo. “A Power-Control Theory of Gender and Religiosity.” Journal for the Scientific Study of Religion 48:2 (2009): 213-231.

Coney, Sandra. Stroppy Sheilas and Gutsy Girls: New Zealand Women of Dash and Daring. N.Z: Tandem Press, 1998.

Confoy, Maryanne; Dorothy A. Lee and Joan Nowotny, eds. Freedom and Entrapment: Women Thinking Theology. Melbourne: Dove, 1995.

"Core Beliefs: The Danvers Statement on Biblical Manhood and Womanhood." (1987). www.cbmw.org/Danvers (accessed 25 April, 2010).

Council on Biblical Manhood and Womanhood, The. www.cbmw.org (accessed 24 February, 2010).

Davidman, L. Tradition in a Rootless World: Women Turn to Orthodox Judaism. Berkeley; Oxford: University of California Press, 1991.

Davidson, Allan K., and Peter J. Lineham. Transplanted Christianity. Palmerston North, N.Z.: Department of History; Massey University, 1997.

Delahunty, Catherine and Sue Kedgley. "Who is Pat Triarchy?” Audio recording, the Green Party of Aotearoa, New Zealand, February 18, 2011.

Dempsey, Paula D. "Review: Godly Women: Fundamentalism and Female Power by Brenda E. Brasher.” Sociology of Religion 60:2 (1999): 204. 
Dray, Stephen. "Women in Church History: An Examination of Pre-reformation Convictions and Practice.” Evangel 21:1 (2003): 22-25.

Du Plessis, Rosemary, and Lynne Alice, eds. Feminist Thought in Aotearoa/New Zealand: Differences and Connections. Auckland, N.Z.: Oxford University Press, 1998.

Du Plessis, Rosemary, and Phillida Bunkle, eds. Feminist Voices: Women's Studies Texts for Aotearoa/New Zealand. Auckland, N.Z.: Oxford University Press, 1992.

Edger, Kailla. "Evangelicalism, Sexual Morality, and Sexual Addiction: Opposing Views and Continued Conflicts.” Journal of Religious Health (2010): 1-17.

Ellingson, Stephen. "Review: Remaking the Godly Marriage: Gender Negotiation in Evangelical Families by John Bartkowski.” Sexuality Research and Social Policy Journal of NSRC 2:1 (2005): 68-70.

Evangelical Alliance. The New Zealand Evangelist. Wellington, N.Z.: New Zealand Electronic Text Centre, 2009.

Evangelical and Ecumenical Women's Caucus. (2000-2010). www.eewc.com (accessed 5 August, 2010).

Evans, Robert. An Evangelical World-View Philosophy. (1993). http://revivals.arkangles.com/books.php (accessed 1 May, 2010).

Evans, Robert, and Roy McKenzie. Evangelical Revivals in New Zealand: A History of Evangelical Revivals in New Zealand and an Outline of Some Basic Principles of Revivals. New Zealand: ColCom Press, 1999.

Fiorenza, Elisabeth Schussler. Discipleship of Equals: A Critical Feminist Ekklesia-logy of Liberation. New York: Crossroad, 1993.

Fiorenza, Elisabeth Schussler. In Memory of Her: A Feminist Theological Reconstruction of Christian Origins. New York: Crossroad, 1983. 
Fitzgerald, Tanya. “To Unite their Strength with Ours: Women in Missionary Work in Aotearoa/New Zealand 1827-45.” The Journal of Pacific History 39:2 (2004): 147-161.

Fogarty, Stephen. "Review: The History of a New Zealand Pentecostal Movement: The New Life Churches of New Zealand from 1946 to 1979 by Brett Knowles.” The Journal of the Society for Pentecostal Studies 23:2 (2001): 318-319.

Frank Parsons, Susan, ed. The Cambridge Companion to Feminist Theology. Cambridge, U.K.: Cambridge University Press, 2002.

Friedan, Betty. The Feminine Mystique. New York: Dell, 1963.

Friedan, Betty. The Second Stage. Cambridge, Mass.: Harvard University Press, 1998.

Fry, Richard, and D’Vera Cohn. “Pew Research Centre: New Economics of Marriage: The Rise of Wives.” (2010). http://pewresearch.org/pubs/1466/economics-marriage-

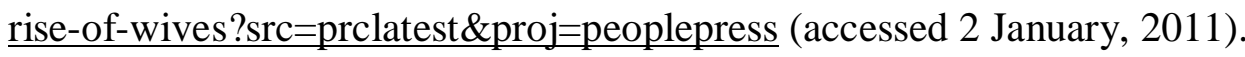

Gallagher, Sally K. Evangelical Identity and Gendered Family Life. New Brunswick, N.J.; London: Rutgers University Press, 2003.

Gallagher, Sally K. “The Marginalization of Evangelical Feminism.” Sociology of Religion 65:3 (2004): 215-237.

Giles, Kevin. Better Together: Equality in Christ. Australia: Acorn Press, 2010.

Giles, Kevin. The Trinity and Subordinationism: The Doctrine of God and the Contemporary Gender Debate. Downers Grove, Illinois: Intervarsity Press, 2002.

Gosling, Les. To Keep the Faith: Westminster Fellowship's Forty Years. Manurewa, N.Z.: Westminster Fellowship, 1990. 
Greer, Germaine. Sex and Destiny: The Politics of Human Fertility. London: Secker and Warburg, 1984.

Griffith, Marie R. God's Daughters: Evangelical Women and the Power of Submission. Berkeley: University of California Press, 1997.

Griffith, Marie R. “Revising Our Assessment of Evangelical Women’s Groups.” Tikkun 13:2 (1998): 18.

Gross, Rita M., ed. Beyond Androcentrism: New Essays on Women and Religion. Missoula, Mont.: Scholars Press for the American Academy of Religion, 1977.

Grudem, Wayne. Evangelical Feminism: A New Path to Liberalism? Wheaton, Illinois: Crossway Books, 2006.

Hampson, Daphne. After Christianity. London: SCM Press, 1996.

Hardy, Ann. "Reporting on Evangelical Christian Protest in the New Zealand Media: The Case for Training in Religion Journalism.” Australian Journalism Review 29:1 (2007): 63-74.

Harris, Brian S. "Revisioning Evangelical Theology: An Exploration, Evaluation and Extension of the Theological Method of Stanley J. Grenz.” PhD Thesis, The University of Auckland, 2007.

Harvey, Bob. “Educator says Christianity and Feminism Go Together." The Ottawa Citizen, 27 January, 1990, I.6.

Hassett, Miranda K. "Reinventing English Evangelicalism, 1966-2001: A Theological and Sociological Study.” Anglican and Episcopal History 77 (2008): 3.

Hendershot, Heather. Shaking the World for Jesus: Media and Conservative Evangelical Culture. Chicago, IL: University of Chicago Press: 2004. 
Heywood, Andrew. Political Ideologies: An Introduction. New York: Palgrave Macmillan, 2003.

Hoggard-Creegan, Nicola. Interview by Lydia Ellis. Tape recording. Laidlaw College: Auckland, 23 July, 2010.

Hoggard-Creegan, Nicola, and Christine Pohl. Living on the Boundaries: Evangelical Women, Feminism and the Theological Academy. Downers Grove, Illinois: InterVarsity Press, 2008.

Holsti, Ole R. Content Analysis for the Social Sciences and the Humanities. Reading, MA: Addison-Wesley Pub. Co., 1969.

Hitchen, John M. "What It Means to be an Evangelical Today - An Antipodean Perspective: Part One - Mapping Our Movement.” EQ 76:1 (2004): 47-64.

Hitchen, John M. "What It Means to be an Evangelical Today - An Antipodean Perspective: Part Two.” EQ 76:2 (2004): 99-115.

Holland, Tom. “Individualism and the People of God.” Evangel 23:3 (2005): 86-91.

Hubbard, A. “For God and Country.” Sunday Star Times, 5 November, 2006, C4.

Hurst, Walter Edmund Wilmhurst. Church Today. Dunedin: J. McIndoe, 1968.

Ingersoll, Julie J. Evangelical Christian Women: War Stories in the Gender Battles. New York: New York University Press, 2003.

Isherwood, Lisa, and Dorothea McEwan, eds. A to Z of Feminist Theology. Sheffield: Sheffield Academic Press, 1996.

James, Colin. "What is the Place of the Sacred in Modern Society?" New Zealand Herald, 25 March 2008, A13. 
Johnson, Phil. "The Neo-Liberal Stealth Offensive." (2010). http://www.9marks.org/ejournal/by-author/phil-johnson (accessed 13 December, 2010).

Johnson, Ron. “The Good News about Evangelicalism: Evangelicalism Isn’t Shrinking and the Young are not Becoming Liberals.” First Things: A Monthly Journal of Religion and Public Life 210 (2011): 12.

Jones, Jennifer. “When Women’s Rights Are Not Our Own.” Muse Feminist Magazine, August 16, 2009, issue 4.

Joyce, Kathryn. “Women’s 'Liberation’ Through Submission: An Evangelical AntiFeminism Is Born.” Religion Dispatches 22 January, 2009. http://www.alternet.org/reproductivejustice/121603/women's 'liberation'_through submission: an evangelical anti-feminism is born / (accessed 14 August, 2010).

Jule, Allyson, and Bettina Tate Pedersen, eds. Being Feminist, Being Christian: Essays from Academia. New York: Palgrave Macmillan, 2006.

Kearney, Celine. Faces of the Goddess: New Zealand Women Talk about Their Spirituality. North Shore City: Tandem Press, 1997.

Kedgley, Sue. “Caught in the Crossfire - Women's Liberation in the Seventies.” Speech, Seventies Conference at Te Papa, Wellington, New Zealand, December 4, 2004.

Kedgley, Sue, and Mary Varnham, eds. Heading Nowhere in a Navy Blue Suit: and Other Tales from the Feminist Revolution. Wellington, N.Z.: Daphne Brasell Associates Press, 1993.

Ker, John M., and Kevin J. Sharpe, eds. Religion's Response to Change: Papers Presented to the Auckland Religious Studies Colloquium University of Auckland, 26-28 August, 1983. Auckland, N.Z.: Auckland University Chaplaincy Publishing Trust, 1985. 
Ker, John M., and Kevin J. Sharpe, eds. Towards an Authentic New Zealand Theology: Proceedings of the 1982 Meetings of the Auckland Theology Forum. Auckland: University of Auckland Chaplaincy Publishing Trust, 1984.

Knowles, Brett. The History of a New Zealand Pentecostal Movement: The New Life Churches of New Zealand from 1946 to 1979. Dunedin, N.Z.: Third Millennium Pub., 1999.

Lampman, Jane. “All Equal Under God, but Submission for Women? Evangelical Group Challenges Claim of a Biblical Basis for Male Leadership.” The Christian Science Monitor (2003): 12.

Lange, Stuart. "A Rising Tide: The Growth of Evangelicalism and Evangelical Identity among Presbyterians, Anglicans and University Students in New Zealand, 1930-1965.” PhD Thesis, University of Otago, 2008.

Langenbach, Lisa. "Women with Children: Evangelical Ministers' View of the Role of Women in Society.” Canadian Review of American Studies 23:4 (1993): 61-71.

Lewis, Andrew R., and Dana Huyser de Bernardo. "Belonging without Belonging: Utilizing Evangelical Self-Identification to Analyze Political Attitudes and Preferences.” Journal for the Scientific Study of Religion 49:1 (2010): 112-126.

Manning, Christel. God Gave Us the Right: Conservative Catholic, Evangelical Protestant and Orthodox Jewish Women Grapple with Feminism. New Brunswick, N.J.; London: Rutgers University Press, 1999.

Marsden, George M. Reforming Fundamentalism: Fuller Seminary and the New Evangelicalism. Grand Rapids, Michigan: W.B. Eerdmans Publishing, 1995.

Marsden, George M. Understanding Fundamentalism and Evangelicalism. Grand Rapids, Michigan: W.B. Eerdmans Publishing, 1991.

Martin, Margaret Reid. Finding the Way: New Zealand Christians Look Forward. Melbourne: Joint Board of Christian Education Australia and New Zealand, 1983. 
McDermott, Gerald. "Evangelicals Divided: Gerald McDermott Describes the Battle between Meliorists and Traditionists to Define Evangelicalism.” First Things: A Monthly Journal of Religion and Public Life 212 (2011): 45.

McElroy, Wendy. "Feminism and Liberty." Speech, the International Society for Individual Liberty’s New Zealand Conference, Rotorua, 2004.

McRobbie, Angela. "Post-Feminism and Popular Culture.” Feminist Media Studies 4:3 (2004): 255-264.

Mill, John Stuart. The Subjection of Women. New York: D. Appleton \& Co., 1869.

Millar, Grace. 'Because We are All Women': The Relationship Between the Ideas of Women's Liberation and the Development of the New Zealand Feminist Movement. MA Thesis, Victoria University of Wellington, 2003.

Miller, Donald E. "Hope Chapel: Revisioning the Foursquare Gospel." in the Annual Meeting of the Society for the Scientific Study of Religion. Washington, DC., 1992.

Miller, Julie B. "Living it Out: Forming Future Feminists: Elisabeth Schussler Fiorenza, Conscientization, and the College Classroom.” Journal of Feminist Studies in Religion 25:1 (2009): 99.

Morris, Paul. "Fragments of Faith: Religion in Contemporary New Zealand." New Zealand Studies 9:1 (1999): 15-21.

Nadar, Sarojini, and Cheryl Potgieter. "Living It Out: Liberated Through Submission? The Worthy Woman's Conference as a Case Study of Formenism.” Journal of Feminist Studies in Religion 26:2 (2010): 141-151.

Neitz, Mary Jo. Charisma and Community: A Study of Religious Commitment. Brunswick, NJ: Transaction Books, 1987. 
Nichol, Christopher, ed. Women and the Church. Wellington: Victoria University Chaplaincy and Religious Studies Department, 1984.

Nichol, Christopher, and James Veitch, eds. Religion in New Zealand. Wellington, N.Z.: The Tertiary Christian Studies Programme of the Combined Chaplaincies and the Religious Studies Dept. at Victoria University of Wellington, 1983.

Padgett, Alan G. "The Bible and Gender Troubles: American Evangelicals Debate Scripture and Submission.” Dialog: A Journal of Theology 47:1 (2008): 21-26.

Patrick, Bruce, ed. New Vision New Zealand Congress 1997. Auckland: Vision New Zealand, 1997.

Patrick, Bruce, ed. New Vision New Zealand Volume II. Auckland: Vision New Zealand, 1997.

Piggin, Stuart. "Preaching the New Birth and the Power of Godliness and not insisting so much on the Form: Recent Studies of (mainly English) Evangelicalism.” Journal of Religious History 33:3 (2009): 366-376.

Quebedeaux, Richard. The Worldly Evangelicals. San Francisco: Harper and Row, 1978.

Ramshaw, Gail. Under the Tree of Life: The Religion of a Feminist Christian. New York: Continuum, 1998.

Randall, Ian. What a Friend we have in Jesus: the Evangelical Tradition. Maryknoll, N.Y.: Orbis Books, 2005.

Roberts, Kyle B. "Locating Popular Religion in the Evangelical Tract: The Roots and Routes of the Dairyman's Daughter.” Early American Studies: An Interdisciplinary Journal 4.1 (2006): 233-270.

Rose, Susan D. "Women Warriors: The Negotiation of Gender in a Charismatic Community.” Sociological Analysis 48:3 (1987): 245-258. 
Ross, Cathy. "Separate Spheres or Shared Dominions?" Transformation: An International Journal of Holistic Mission Studies 23 (2008): 228-235.

Rosson, Thomas, and Dail Fields. "Cultural Influences on the Growth in Evangelical Christianity: A Longitudinal Study of 49 countries.” Review of Religious Research 49:3 (2008): 269-289.

Roxborogh, John. "Identity, History and the Evangelical Landscape in New Zealand.” (1999). www.roxborogh.com/articles/evangelicalidentity.htm (accessed 5 March, 2010).

Ruether, Rosemary Radford. Sexism and God-Talk: Toward a Feminist Theology. Boston: Beacon Press, 1983.

Russell, Letty M. Household of Freedom: Authority in Feminist Theology. Philadelphia: Westminster Press, 1987.

Saiving, Valerie. “The Human Situation: A Feminine View.” Journal of Religion 40 (1960): 100-112.

Sawyer, Deborah F., and Diane M. Collier, eds. Is there a Future for Feminist Theology? Sheffield: Sheffield Academic Press, 1999.

Schreiber, Ronnee. “Injecting a Woman’s Voice: Conservative Women’s Organizations, Gender Consciousness, and the Expression of Women’s Policy Preferences.” Sex Roles: A Journal of Research 47:7/8 (2002): 331-342.

SermonAudio.com. www.sermonaudio.com (accessed 5 June, 2010).

Sharpe, Kevin J., ed. Religion and New Zealand's Future: Proceedings of the Seventh Auckland Religious Studies Colloquium, 2-3 May, 1981. Palmerston North, N.Z.: Dunmore, 1982. 
Shibley, Mark A. "Contemporary Evangelicals: Born-Again and World Affirming." Annals of the American Academy of Political and Social Science 558 (1998): 67-87.

Simpson, Jane Mary Ramsay. Joseph W. Kemp and the Impact of American Fundamentalism in New Zealand. B.A. (Hons.) degree, University of Waikato, 1987.

Smedley, Cynthia Toms. "Review: The Unlikely Disciple: A Sinner's Semester at America’s Holiest University.” Christian Higher Education 9:4 (2010): 361-365.

Sowinska, Alicja. “Ambiguous Women: Debates within American Evangelical Feminism.” European Journal of American Culture 26:3 (2007): 167-180.

Spencer, Aida Besancon; William David Spencer, and Mimi Haddad, eds. Global Voices on Biblical Equality: Women and Men Serving Together in the Church. Oregon: Wipf and Stock Publishers, 2008.

Statistics New Zealand. (2000). "Religion and Ethnicity Source: New Zealand Official Yearbook 2000.”

http://www2.stats.govt.nz/domino/external/web/nzstories.nsf/0/553e95d870abb153cc25 6b1e0080ad44?OpenDocument (accessed 19 May, 2010).

Statistics New Zealand. (2001). "Census Snapshot: Cultural Diversity.” http://www.stats.govt.nz/browse for stats/population/census counts/census -snapshot-cultural-diversity.aspx (accessed 2 June, 2010).

Statistics New Zealand. (2005). "Focusing on Women.” http://www.stats.govt.nz/browse_for_stats/people_and_communities/women/focusingon-women.aspx (accessed 2 June, 2010).

Statistics New Zealand. (2006). “QuickStats about Culture and Identity.” http://www.stats.govt.nz/Census/2006CensusHomePage/QuickStats/quickstat s-about-a-subject/culture-and-identity/religious-affiliation.aspx (accessed 2 June, 2010). 
Stenhouse, John, and Brett Knowles, eds. Future of Christianity: Historical, Sociological, Political and Theological Perspectives from New Zealand. Adelaide: ATF Press, 2004.

Stocks, J. "To Stay or to Leave? Organizational Legitimacy in the Struggle for Change among Evangelical Feminists.” in Contemporary American Religion: An Ethnographic Reader edited by P. Edgell Becker and N. L. Eiesland. Walnut Creek: Alta Mira Press, 1997.

Storkey, Elaine. What's Right with Feminism? London: SPCK, 1985.

Svelmoe, William. “Christianity Reborn: The Global Expansion of Evangelicalism in the Twentieth Century.” International Bulletin of Missionary Research 29 (2005): 4.

Sweeney, Douglas A. "The Essential Evangelicalism Dialectic: The Historiography of the Early Neo-Evangelical Movement and the Observer-Participant Dilemma." Church History: Studies in Christianity and Culture 60:1 (1991): 70-84.

Sweet, Leonard I. The Minister's Wife: Her Role in Nineteenth-Century American Evangelicalism. Philadelphia: Temple University Press, 1983.

Talbert-Wettler, Betty. "Secular Feminist Religious Metaphor and Christianity." Journal of the Evangelical Theological Society 38:1 (1995): 77-92.

Tarrezz, Shondrah Nash. "The Changing of the Gods: Abused Christian Wives and their Hermeneutic Revision of Gender, Power, and Spousal Conduct.” Qualitative Sociology 29 (2006): 195-209.

Tasker, Yvonne, and Diane Negra. Interrogating Postfeminism: Gender and the Politics of Popular Culture. Durham, N.C.: Duke University Press, 2008.

Thagard, Paul. “The Emotional Coherence of Religion.” Journal of Cognition and Culture 5:1 (2005): 2. 
Thompson, Denise. Radical Feminism Today. London: SAGE Publications Ltd., 2001.

Tichenor, Veronica. “Maintaining Men’s Dominance: Negotiating Identity and Power When She Earns More.” Sex Roles: A Journal of Research 53:3/4 (2005): 191-205.

Tidball, Derek. "Post-War Evangelical Theology: A Generational Perspective." Evangelical Quarterly 81:2 (2009): 145-160.

Tracy, Steven R. "What Does 'Submit in Everything' Really Mean? The Nature and Scope of Marital Submission.” TRINJ 29 (2009): 285-312.

Trueman, Carl R. Wages of Spin: Critical Writings on Historic and Contemporary Evangelicalism. Fearn: Mentor, 2004.

Wainwright, Elaine. Women Healing/Healing Women: The Genderisation of Healing in Early Christianity. London: Equinox Publishing Ltd., 2006.

Ward, Kevin. “Does a Rose by any Other Name Still Smell the Same?” Stimulus 17:3 (2009): 18-23.

Ward, Rosie. Growing Women Leaders. CPAS: The Bible Reading Fellowship, 2008.

Waring, Marilyn. Women, Politics and Power. Wellington, N.Z: Unwin, 1985.

Waring, Marilyn; Gaye Greenwood and Christine Pintat. Politics: Women's Insight. Analysis of the IPU Survey. New York: Inter-Parliamentary Union, 2000.

Webster, A. Spiral of Values: The Flow from Survival Values to Global Consciousness in New Zealand. Hawera, N.Z.: Alpha Publications, 2001.

West, Angela. Deadly Innocence: Feminist Theology and the Mythology of Sin. New York: Cassell, 1995. 
Wilcox, Clyde. "Evangelicals and the Moral Majority.” Journal for the Scientific Study of Religion 28:4 (1989): 400-414.

Wilcox, Clyde. “Feminism and Anti-Feminism among Evangelical Women.” Political Research Quarterly 42 (1989): 147.

Witt, Susan D. "Parental Influence on Children's Socialization to Gender Roles." Adolescence 32 (1997).

Wolbrecht, Christina. The Politics of Women's Rights: Parties, Positions and Change. Princeton, N.J.: Princeton University Press, 2000.

Wollstonecraft, Mary. A Vindication of the Rights of Women. New York: Cosimo, 2008.

Women's Studies Association of New Zealand. "Kete of Women - Women's Lore.” Women's Studies Association of New Zealand Conference 2008, Invercargill, 1-3 February, 2008.

Women's Studies Association of New Zealand. "Sustaining Women, Regenerating Feminisms.” Women’s Studies Association of New Zealand Conference, Auckland, 2527 November, 2005.

Worsfold, James E. A History of the Charismatic Movements in New Zealand. Bradford: Julian Literature Trust, 1974.

Young, Katherine K. "Review: Having Your Cake and Eating It Too: Feminism and Religion.” Journal of the American Academy of Religion 67:1 (1999): 167-184.

Zohrab, Peter. "State Religion is Feminism." The Dominion Post, May 22, 2006, Features. 